\title{
oiioiioii To Be a Network Society: A Cross-National oiroiioi oiioiioii Perspective on the Internet in Britain
}

\author{
Ellen J. Helsper, William Dutton and Monica Gerber \\ Oxford Internet Institute \\ University of Oxford \\ 1 St Giles Oxford OX1 3JS
}

This working paper was prepared for the Oxford Internet Surveys (OxIS) input to the World Internet Project (WIP). The authors thank colleagues in the WIP for their insights relevant to the worldwide diffusion and impact of the Internet. This paper aims to complement an international report (WIP 2008) by focusing on Britain's place in the worldwide ecology of the Internet.

\begin{abstract}
After years of collective indecision, Britain shifted to become a full participant in an increasingly networked world; supporting the diffusion of the Internet, broadband access, and its use for an increasingly wide range of activities.

This paper compares Britain with other European nations and the wider world in its adoption and use of the Internet. It draws from the Oxford Internet Surveys (OxIS) and the World Internet Project (WIP), along with other publicly available data to compare and contrast patterns of adoption, use and impact.

Comparative research places Britain in the mainstream of other networked nations. Britons were not early adopters, nor were they laggards. Most have integrated the Internet into their everyday life and work complementing interpersonal communication and other media. In several important respects, Britons have become fuller participants in the network society than many others, such as in using the Internet more often for a wider range of activities. Similar to most developed nations, Britain faces enduring issues over digital inclusion, and in whether to keep pace with global developments in high-speed Internet access and mobile broadband Internet use, in the face of calls for greater regulation of content.
\end{abstract}

(C) University of Oxford for the Oxford Internet Institute 2009. This work may be copied freely for non-commercial research and study. If you wish to do any of the other acts restricted by the copyright you should apply in writing to the Director of the Institute at 1 St Giles', Oxford OX1 3JS, England. 


\section{Introduction}

In 2008, world-wide Internet use approached 1.5 billion people. ${ }^{1}$ With over 40 million Internet users ${ }^{2}$, the United Kingdom thus represents less than three percent of the world's users. While many trends in the use and impact of the Internet are similar across the world, differing mainly in the timing and speed of diffusion, academics and policy-makers have identified unique national patterns that reflect the social, economic and cultural heritage of each country and region. We do not yet fully understand where Britain sits amid global patterns of Internet diffusion and use. We, therefore, ask in this paper if Britain follows the patterns of other nations, or is its uptake and use more characteristic of Europe, or indeed, is it unique to Britain?

On several dimensions of cross-national comparison, Britain is positioned in the mainstream of countries in which the Internet has been widely adopted by the public. Patterns of adoption and use are not on the leading-edge, but neither can the UK be characterized as a laggard. There were early years in the diffusion of the Internet when Britain stalled behind the US and other developed nations in the take-up of the Internet. For example, only about one-third of Britons used the Internet in 2001. During that period, many opinion-leaders doubted the need for online communications in light of the quality of Britain's telecommunication and media environment, and found their views reinforced when the world wide dotcom bubble burst. Many then doubted the need for broadband services, being relatively slow to embrace broadband until 2003, when a major campaign for broadband Internet was orchestrated (Dutton et al 2004).

However, since 2005, Britons have become similar in uptake of the Internet to most nations of Europe and the developed economies worldwide, and they have started using the Internet for an increasing number of activities. From 2007, concern shifted from whether or not to embrace the Internet, to how to accommodate, maintain and enhance more traditional media and communication with the Internet in a period of growing use and convergence. For example, discussion of journalism and the press shifted from debate over whether the Internet would become a threat to the newspaper to discussion of how newspapers could use the Internet more strategically to support the news business. ${ }^{3}$ That said, concerns over the safety of children and radicalisation of certain groups in society, for example, have generated increasing support for more regulation of Internet content.

This paper will first discuss the current and historical position of Britain as regards access and infrastructure. This is followed by a closer look at how Britain compares with other countries in terms of the types of Internet uses people undertake. A brief overview of digital divides and attitudes towards the Internet in Britain and other countries is part of this discussion.

\footnotetext{
${ }^{1}$ http://www.Internetworldstats.com/stats.htm

2 http://www. Internetworldstats.com/stats4.htm\#europe

${ }^{3}$ A recent illustration of this shift in opinion was evident at a conference of the Reuter's Institute for the Study of Journalism at which the keynote speaker, Arthur Sulzberger, the publisher of the New York Times, argued that his paper was strategically exploiting the Internet as a means for delivering the news. This was met with general concurrence by an international but also UK audience. See:

http://reutersinstitute.politics.ox.ac.uk/about/news/item/article/reuters-memorial-lecture2008.html
} 


\section{Methods and Data}

This paper draws on international data to place Britain in a regional and global context. It draws most data from the survey research conducted in Britain from 2003 through 2007 as part of the Oxford Internet Surveys (OxIS). OxIS findings are based on face-to-face interviews with national, multi-stage probability samples of Britons 14 years of age and older, who were living in England, Scotland or Wales (Dutton, di Gennaro, and Hargrave 2005; Dutton and Helsper 2007). ${ }^{4}$ Our conduct and analyses of these surveys enable us to speak most confidently about Internet trends in Britain.

However, OxIS is one part of a larger international collaboration, the World Internet Project (WIP). This project engages over two dozen nations in the design of common questions and data sets for cross-national comparisons (WIP, 2008). Each nation has varied approaches to conducting its national surveys, often basing their research on telephone surveys, but not exclusively, such as in the aforementioned case of Britain where face-to-face interviews were undertaken. ${ }^{5}$

These OxIS and WIP data sources are supplemented by Internet statistics collected by national and regional bodies, such as the European Union and the Organization for Economic Cooperation and Development (OECD). Together, these publicly available data sources enable us to gain an overview of Britain in its global context from the early years of the $21^{\text {st }}$ Century through 2008 .

\section{The Diffusion of the Internet}

The diffusion of the Internet throughout the world varies considerably by region on at least two major dimensions, which might be called 'throw weight' or the size of the Internet population, and penetration, the proportion of the public using the Internet. Figure 1 lists major regions in order of the proportion of the population that uses the Internet.

\footnotetext{
${ }^{4}$ The sampling strategy and methods along with the exact questionnaires given to field staff are provided in detail at http://www.oii.ox.ac.uk/microsites/oxis/methodology.cfm

${ }^{5}$ Information about WIP nations, reports and data sets can be found at:

http://www.worldlnternetproject.net/
} 
Figure 1. Regional Diffusion: Number of Users and Proportion of Users by World Regions

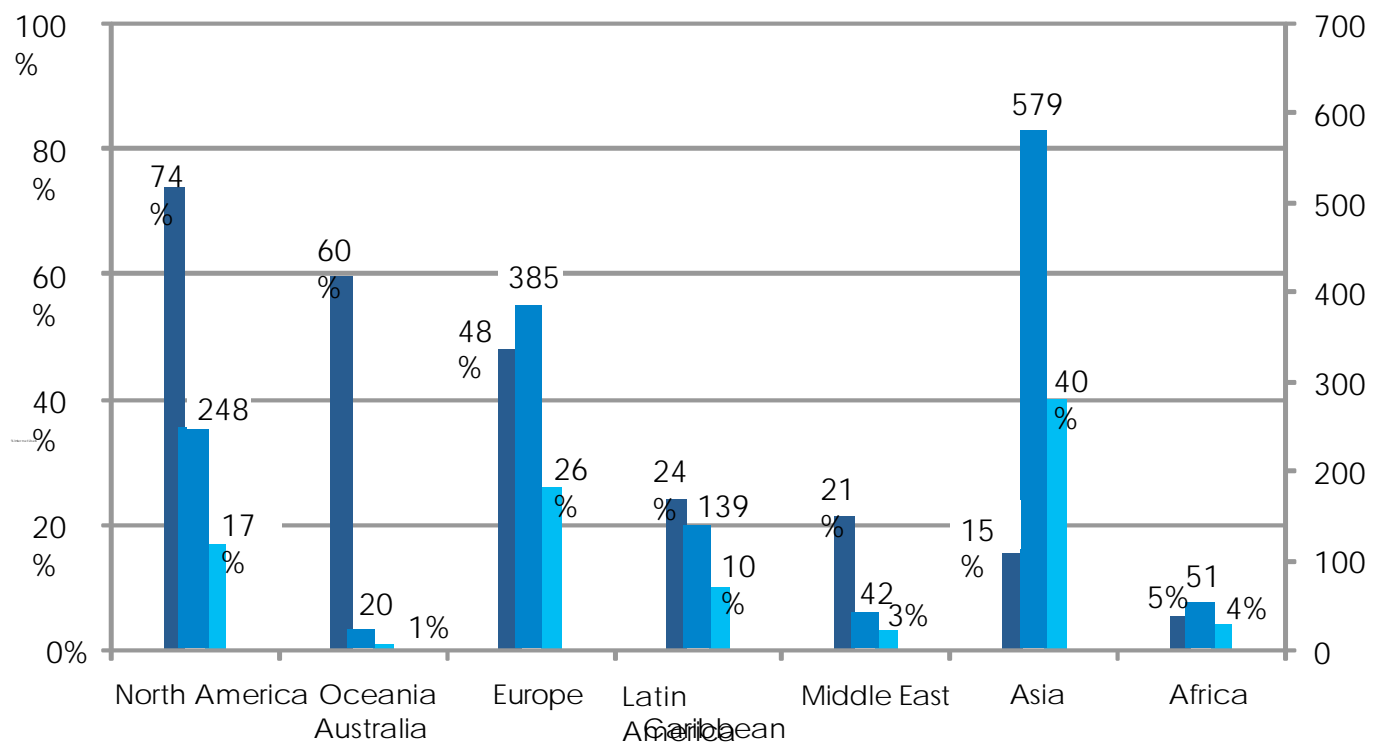

Source: Internet World Stats (2007) at www.internetworldstats.com/stats.htm

As shown in Figure 1, Africa has the lowest level of Internet use at just over 5 percent, followed by Asia, the Middle East, Latin America and the Caribbean, Europe, Oceania and Australia, and finally North America, which has the highest proportion of the population online, approaching three-fourths (74 percent) of the public. There is a substantial gap between Europe, with about one-half of the population online and North America as well as Oceania and Australia, which are on a higher level, closer to 60 percent.

Figure 1 also shows that while penetration rates are low in Asia, its throw-weight is great. Internet users in Asia make up a large part of the total global number of Internet users online; with 579 million Internet users (40 percent of the global Internet user population) Asian countries constitute a large market and are a growing force in the production and consumption of content. Overall, the emerging markets of Africa, Asia, the Middle East and Latin America and the Caribbean are poised to overtake the developed regions in numbers of Internet users within the near-future, particularly with the diffusion of broadband mobile access.

International statistics show that the US was one of the first countries to reach over 50 percent diffusion. In the UK the Office of National Statistics (ONS) found that 2003 was the first year in which at least half of the UK households were connected to the Internet (Figure 2). OxIS surveys estimated a larger proportion of Internet users, closer to 58 percent of Britons 14 years of age and older by 2003, increasing slowly from 61 percent in 2005 to 66 percent in 2007. The trend data suggest a plateau of use at around 70 percent. 
Figure 2. Households in Britain with access to the Internet

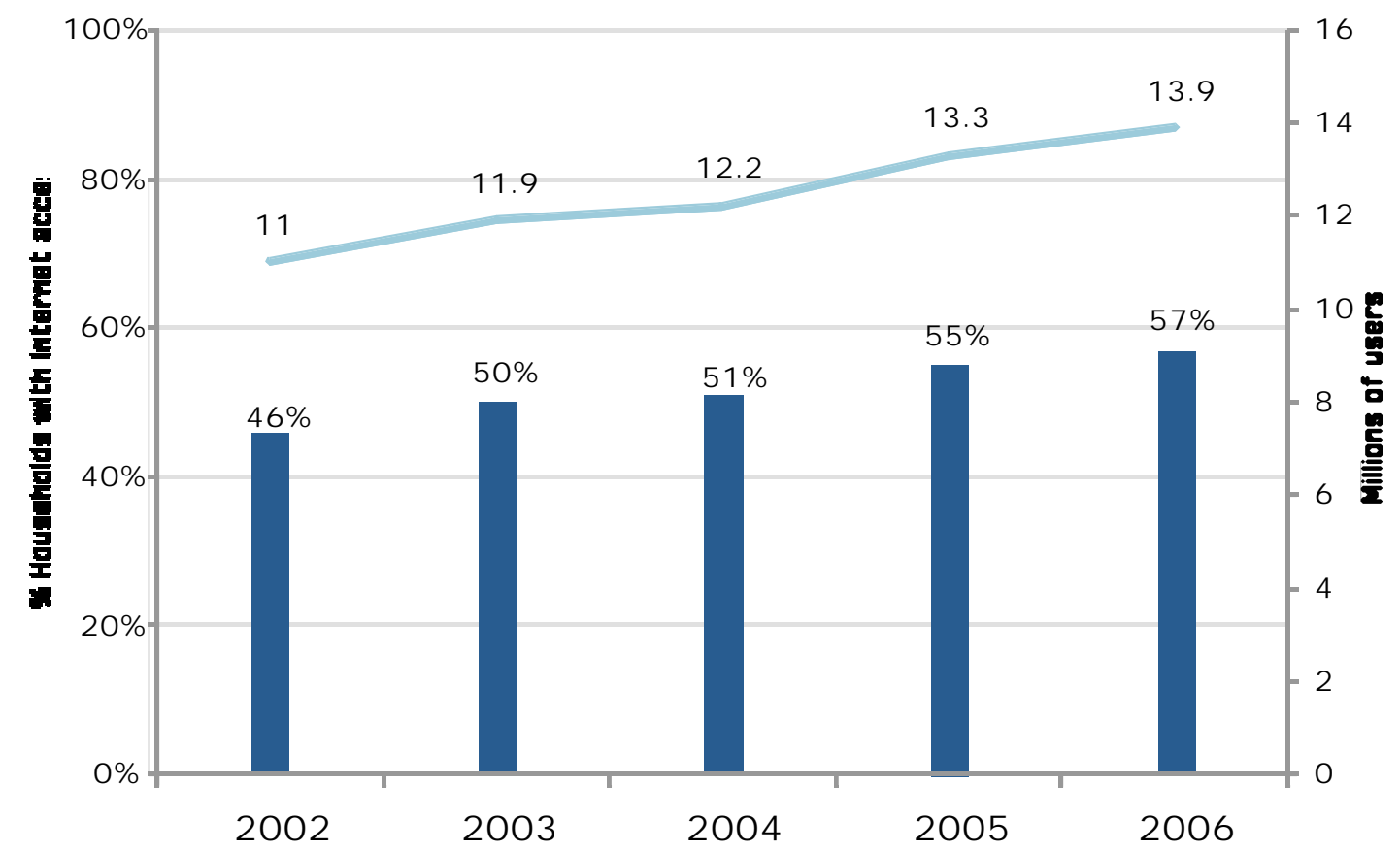

Source: National Statistics Omnibus Survey; Northern Ireland Omnibus Survey; Survey of Internet Service Providers (Office of National Statistics, 2007).

The Internet diffused rapidly in Britain from 2000, when it reached less than one-third of Britons, to 2007 when nearly two-thirds of Britain were online. It was in the late1990s, and early 2000s, that the UK was at a point of some indecision. For example, a major UK social science research programme questioned the continued significance of the Internet. ${ }^{6}$ Since 2003, Internet diffusion has continued to increase gradually, although trend data suggest that it might have reached a plateau, reaching 66 percent of the population 14 years of age and over in 2007. That said, the number and proportion of Britons who have access to the Internet continues to increase albeit it gradually.

\section{Internet Diffusion and Economic Development}

Access to information and communication technologies (ICTs) is seen as important to a nation's development in the current globally networked environment. Widespread Internet access is thought to provide a country with the tools to overcome economic disadvantages by providing access to global education and business opportunities. This is why economic indicators such as GDP are often linked to Internet diffusion to provide benchmarks about a country's position on both an economic and a digital scale.

The pace and level of diffusion of the Internet has placed Britain in a position that is in line with its level of economic development relative to other nations. For example, Figure 3 shows the relationship between Internet access and economic development,

\footnotetext{
${ }^{6}$ The Economic and Social Research Council programme on the virtual society was renamed the 'Virtual Society? Programme, highlighting the uncertainty over its long-term significance. See: http://virtualsociety.sbs.ox.ac.uk/ One of the research projects highlighted by the programme wrote of the Internet as a fad (Wyatt, et al 2002).
} 
as reflected in the proportion of the public with access to the Internet, and the percent of GDP across the 25 nations of Europe.

Figure 3. Regression of Internet Access and Economic Development in Europe

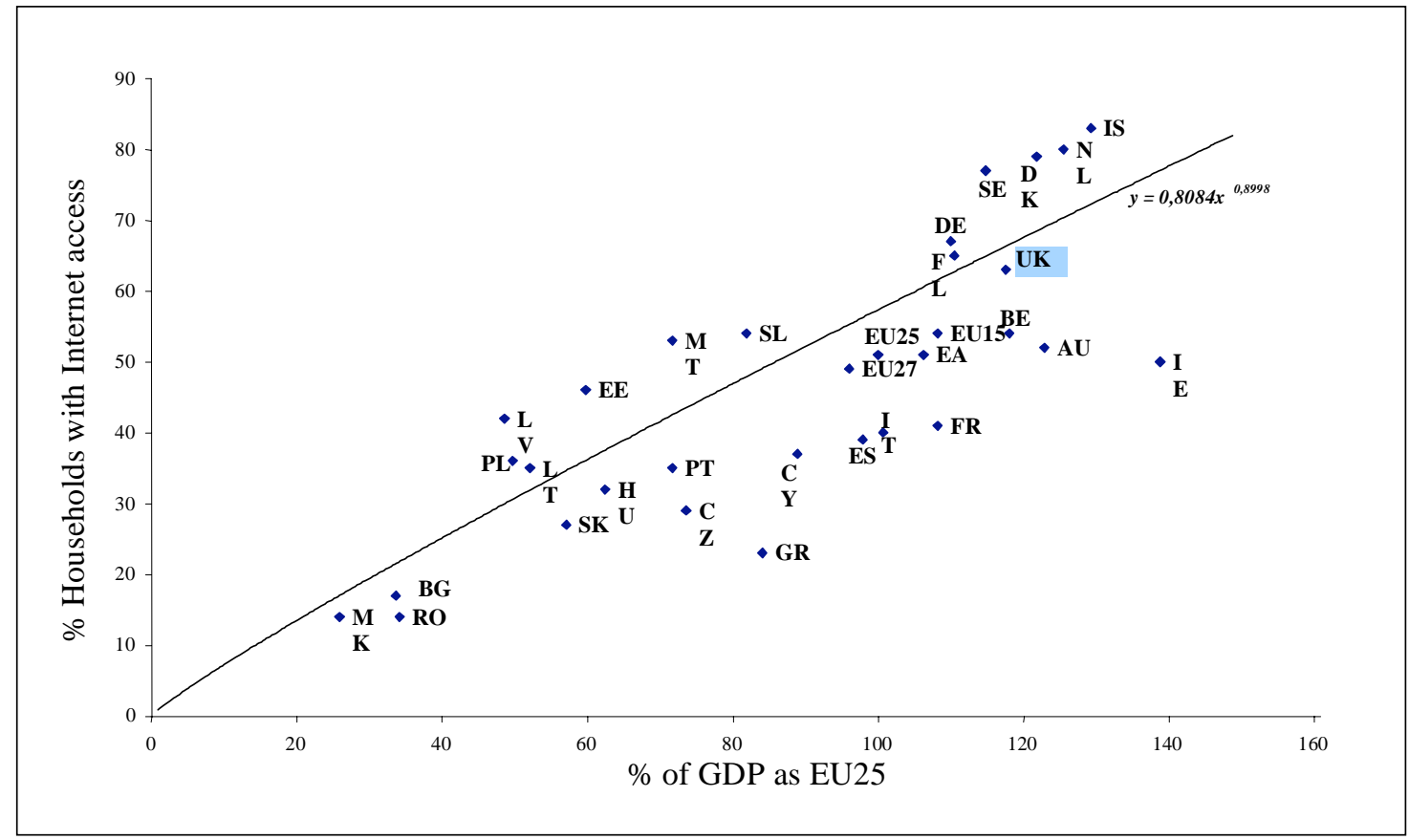

Source: Analyses conducted by Martin Dimov

Similarly, looking beyond Europe, the WIP findings confirm that, in 2007, Britain was neither a forerunner nor a laggard in relation to the uptake of the Internet by individuals. Depending on the region that it is compared with, Britain is either high or average in its rate of Internet diffusion. Within a European context the UK was ahead of Eastern Europe but behind Sweden and most Scandinavian countries as regards the proportion of the public that uses the Internet. The Internet use rates are also lower than in other English speaking post-industrial nations, such as the US, Australia, Canada and New Zealand. On average two thirds (66 percent) of people in the UK use the Internet and access it primarily from home, in comparison to around 76 percent in the other English speaking countries.

\section{Embedding the Internet in the Household and Everyday Life}

From 2003 through 2007 the Internet became more integrated into everyday life and work in Britain. From the early days of diffusion, the primary base for Internet access was from a personal computer in the household. Extensions of Internet access via mobile technologies and remote locations, from schools to cyber-cafes are in general complementary to household access, as the household PC remains the primary point for accessing and using the Internet. This also suggests that despite many forecasts of new platforms for Internet access, such as the mobile phone, the diffusion of personal computers remains a major constraint on the further uptake of the Internet in Britain.

One of the most dramatic trends from 2003 through 2007 has been the diffusion of broadband Internet, enabling most Internet households in Britain to move away from 
dial-up modems to 'always on' access (see Figure 4). Broadband diffusion has enabled the Internet to become more integrated into everyday life and work.

Figure 4. Broadband penetration
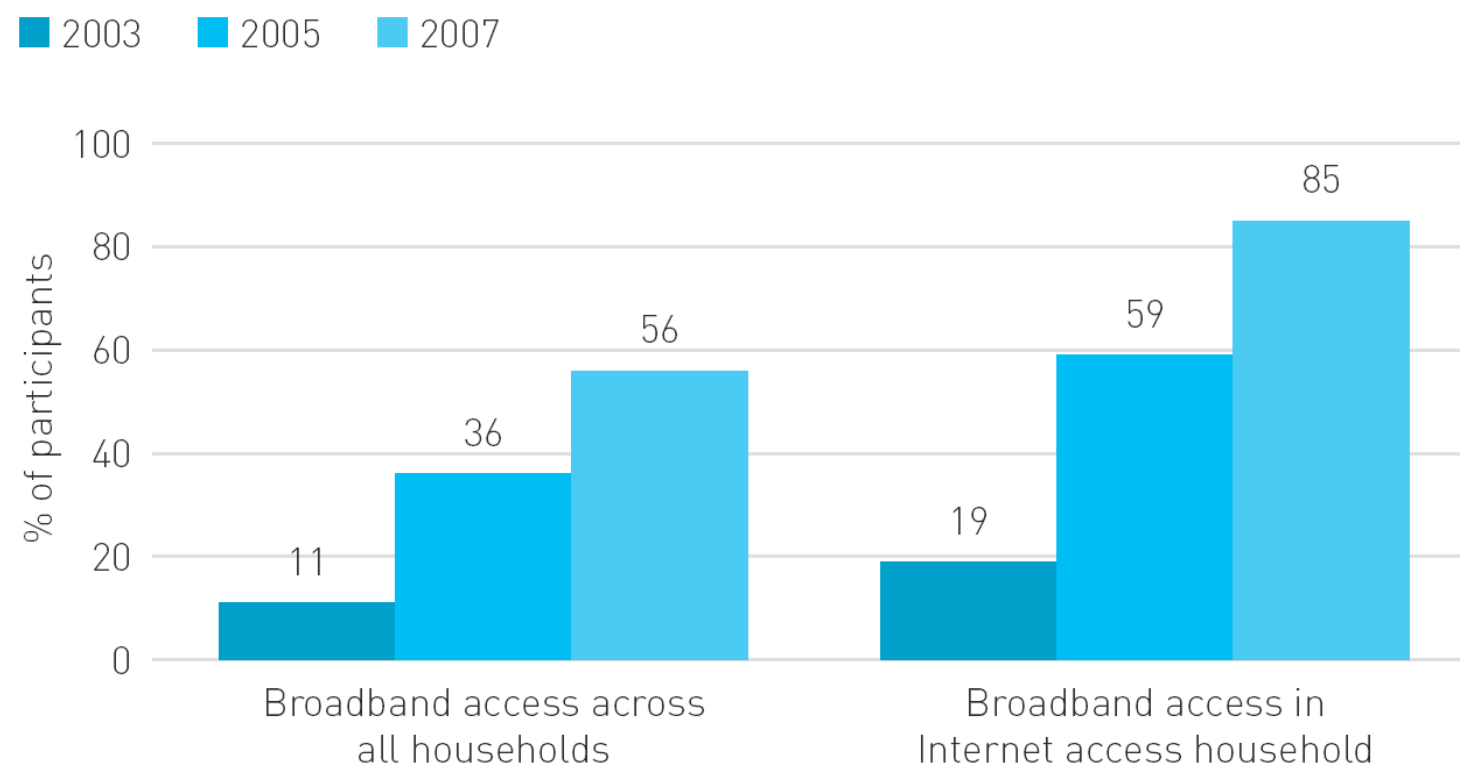

Source: OxIS (Dutton \& Helsper 2007)

Within Europe, Britain has comparatively high levels of broadband penetration. The 2007 Eurobarometer places it amongst the 10 countries with the highest Internet penetration rates (Special Eurobarometer $293^{7}$ ). In general the Scandinavian and Northern European countries have similar or higher broadband penetration rates while Eastern and Southern European regions have lower rates.

Britain's position relative to other nations is in part related to levels of economic inequality. Figure 5 shows the relationship between levels of income inequality, as measured by the Gini coefficient, and the level of broadband access. As illustrated by this figure, Britain's level of broadband diffusion is somewhat higher than expected on the basis of income inequality, possibly reflecting the competitive pricing of broadband Internet access in the nation.

7 http://ec.europa.eu/public_opinion/archives/ebs/ebs_293_full_en.pdf 
Figure 5. Relation between Broadband subscribers and Gini coefficients

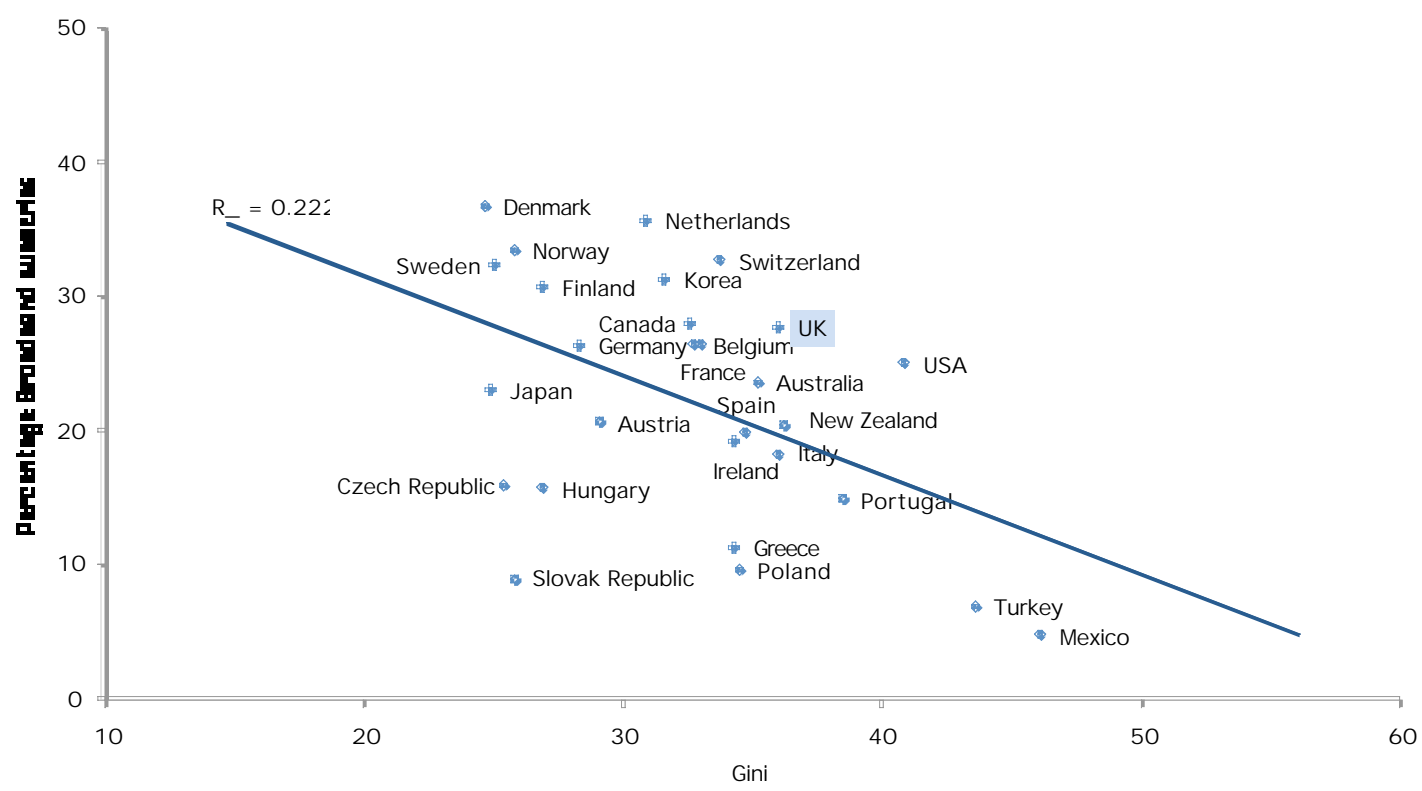

Source: OeCD at http://www.oecd.org/sti/ict/broadband

Notwithstanding average to high rates of diffusion, WIP data shows that Britons have been online for shorter average periods of time than users in most other countries (5.3 years, for example, compared with 8.1 years in Sweden and 6.5 years in Israel) with the exception of the Eastern European countries and Colombia. This reflects the earlier point that Britons were initially hesitant to take up technologies like the Internet and suggests that the majority started to participate in the networked society somewhat later than in comparatively developed countries.

Intensity of Use

However, now that they are on Internet, Britons seem to have embraced it fully. For example, WIP shows that, in terms of weekly hours of use, the UK is among the countries with the highest use at home (10.6 hours per week) and at work (6.9 hours per week). Britons who use the Internet report spending more time online than users in any of the other European countries for which we have data. Globally, only users in Singapore and Macao say that they use the Internet more. While self-reported time use is often unreliable, this general pattern, which shows Britain as slower in the uptake of the Internet, but high in intensity of use, once online, repeats itself in a number of different areas.

Likewise, while Britain was relatively late in relation to other nations of Northern Europe in widespread acceptance of broadband technologies, its acceptance of wireless connections to the Internet, such as mobile phones and wireless laptop access, such as $\mathrm{WiFi}$, has been more rapid than in many other nations with high Internet penetration rates. Both the Eurobarometer surveys and OxIS suggest that in Britain, 44 percent of Internet users access the Internet through a wireless device. The only country in WIP which had a more extensive use of wireless devices was Sweden (74 percent). In comparison, in the Eastern European countries participating in WIP less than 15 percent of Internet users accessed the Internet through a wireless device in 2007. 


\section{Digital divides}

Digital divides can be defined as the differences in access and use of the Internet between different groups in society. Britain, in comparison to other WIP countries, has average to low divides in access in terms of gender, education, age and income. In a European context the differences in Britain are smaller than those in the Eastern European countries, but inequalities are larger than in some Northern European nations, such as Sweden. A detailed analysis of the OxIS 2007 survey data (Helsper 2008) suggests that these divides do not seem to have diminished greatly in Britain over the past half decade.

In the rest of this section, we briefly discuss gender, education, age and income divides in Britain and compare them with the situation in other countries that participate in the World Internet Project (WIP).

\section{Gender Divides}

In Britain, gaps in Internet use between men and women have remained steady at about five percentage points since 2003. While this difference is small, men continue to be significantly more involved with the Internet than women. The differences between men and women in the other English-speaking WIP countries were on average no more than 3 percentage points, very similar to the gender divide that exists in Britain. The US and Sweden were the only two countries in WIP in which surveys indicated that women were slightly more likely to use the Internet than men. In the US, for example, 73 percent of women use the Internet compared with 71 percent of men.

\section{Educational Divides}

A strong factor in relation to digital divides at a global level, as well as in Britain, is education. OxIS shows that respondents in Britain who are currently at university are over four times more likely to use the Internet than respondents whose highest qualification is primary school or lower. This divide is much larger than that observed in other countries with high Internet diffusion rates, such as Sweden and the US, where those at university are only twice as likely to use the Internet. However, the British digital divide based on education is minor compared to the differences observed in other English-speaking countries, and the Eastern European countries. On a global level Britain is, therefore, neither extremely unequal in terms of educational divides nor extremely equal.

\section{Generational Divides}

OxIS has consistently found age to be an important factor in relation to digital divides. For example, 18-24 year old British respondents (86 percent use the Internet) were almost three times more likely to use the Internet than respondents older than 65 (32 percent use the Internet). This same pattern is repeated globally (Figure 6). The educational digital divide in Britain was most similar to that in other WIP countries with high diffusion rates, such as Sweden and the English-speaking countries, and smaller than in countries with lower diffusion rates, such as the Eastern European 
countries. In Hungary for example, 18 to 24 year olds were 16 times more likely to use the internet than over 65 year olds.

Figure 6. Internet use by age

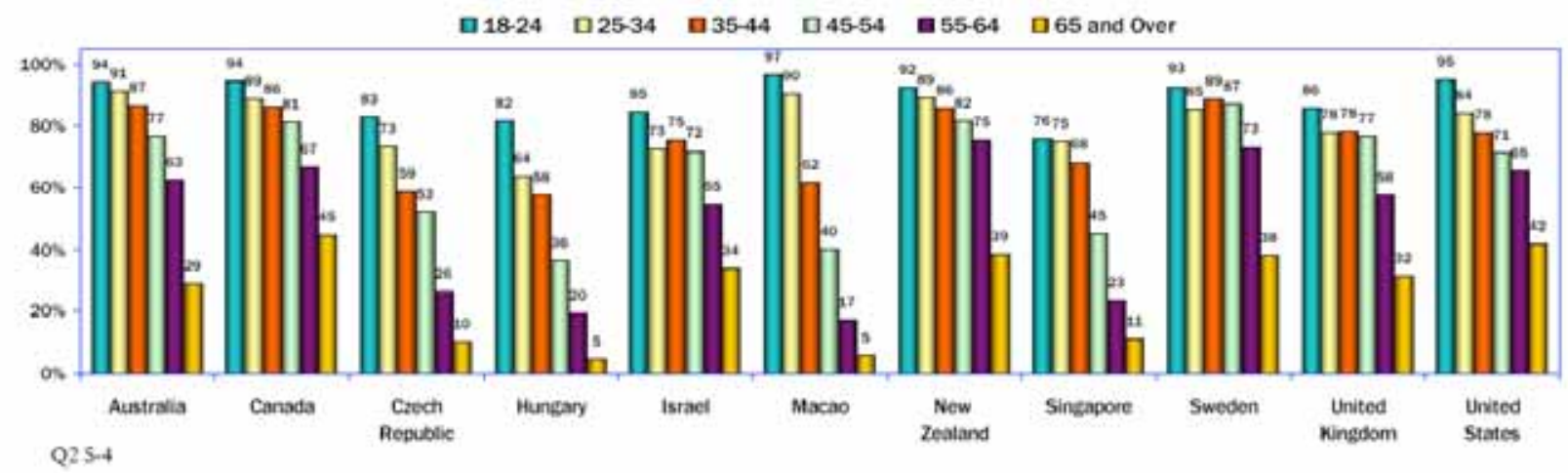

Source: World Internet Project International Report 2009 (p.66)

Other studies, such as the Eurobarometer's 'E-Communications Household Survey', support the observation that age is one of the most important factors in relation to Internet access across Europe. Differences in access to high quality Internet connections (ie. Broadband) between age groups are large in both new member states and in the other EU countries (Figure 7).

Figure 7. Broadband Access by Age

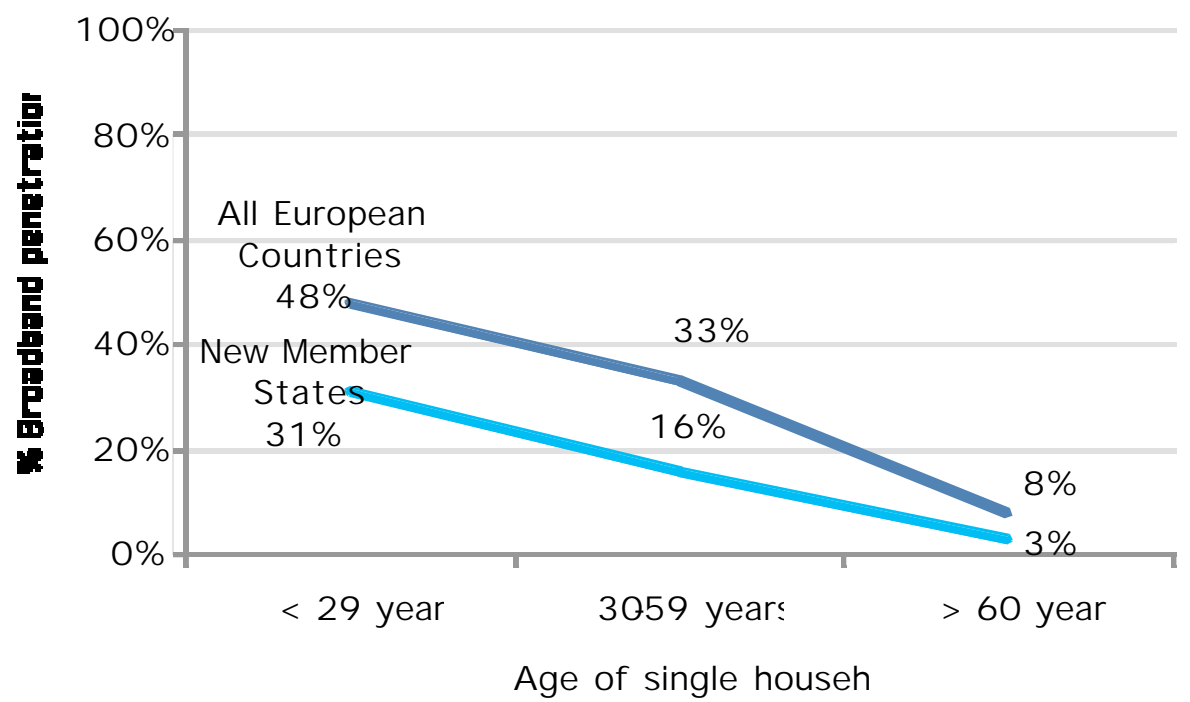

Source: Eurobarometer (2008)

The differences between the new member states and the other European countries were smallest in the older age groups; 8 percent of the individuals over 60 years old used the Internet in all European countries, in comparison with 3 percent in the new member states. 


\section{Income Divides}

Since education and age are clearly related to Internet use, it follows that income divides in Internet use are important as well. OxIS 2007 showed that Britons in higher income brackets were 1.7 times more likely to use the Internet than those in lower income brackets (Figure 8). This corresponds to 85 percent of Internet users in the highest income group and 51 percent of users in the lower income group.

\section{Figure 8. Digital Divide and Gini coefficients}

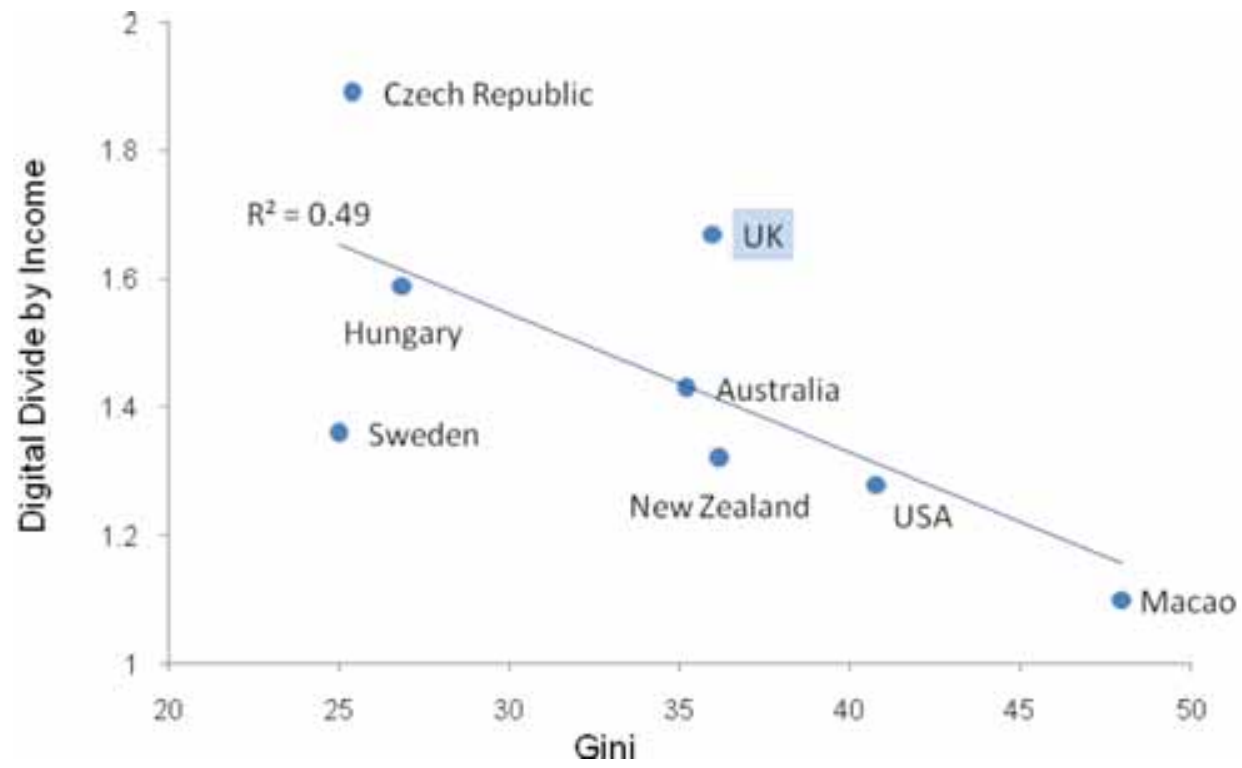

Source: World Internet Project (2007) and OeCD data for the Gini coefficients

Note: Digital divide by income was calculated according to the following formula: Percentage that uses the Internet in the Upper 50\% Income group divided by the percentage that uses the Internet in the Lowest $50 \%$. In the UK the dividing point was £25,000.

Figure 8 shows that the UK has a relatively large digital divide by income in comparison to the socio-economic inequality that exists in the country. Similar to the gender and educational divides discussed earlier, these inequalities are larger than those in other English speaking countries, but smaller than in countries with lower Internet diffusion. To illustrate this point, in Sweden those in the upper 50 percent of the income distribution were 1.4 times as likely to use the Internet than those in the lower 50 percent while in the Czech Republic the higher income group was almost twice as likely to use the Internet.

\section{Digital Exclusion or Digital Choice?}

Digital divides are often interpreted in terms of digital exclusion. That is, people are seen to lack the socio-economic resources to get connected to the Internet. However, some people choose not to use the Internet even though they have the resources to get access or to acquire digital skills. Therefore a distinction should be made between digital exclusion and digital choice when trying to explain non-use of the Internet. Earlier we demonstrated that digital divides in the UK are in some instances larger than expected based on the income distribution in the UK, especially when compared with other countries with high Internet penetrations. In countries 
where socio-economic differences are not reflected proportionally in digital inequality we might assume that digital choice plays a larger role than in those countries where these two types of inequalities are similar.

OxIS shows that one of the most common reasons people in Britain cite for not using the Internet is not having enough skills, or being confused by the technology and a lack of access (Figure 9). But of equal significance is 'lack of interest' in the technology.

Figure 9. Reasons why users and non-users do not use the Internet

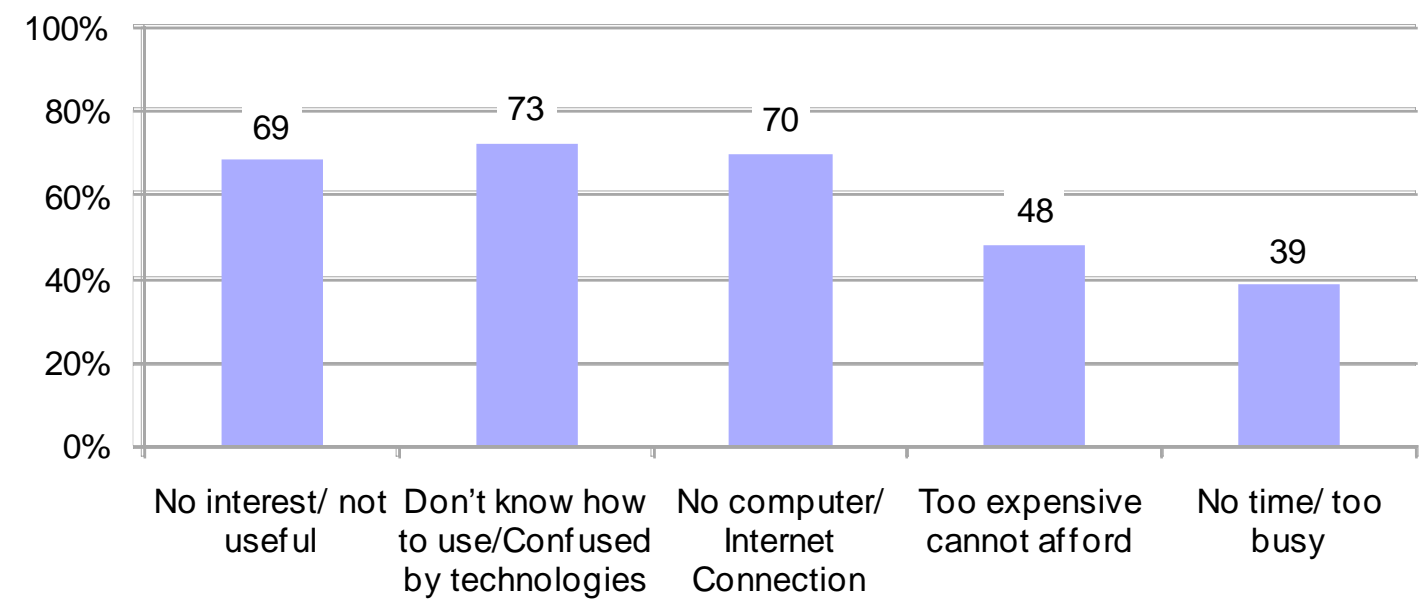

OxIS Base. Adult Non and Ex-users of the Internet ( $N=762)$

Note: In WIP ex-and non-users were asked 'What is the main reason you DO NOT use the Internet?'

Both the Eurobarometer and the WIP studies confirm that in most countries, a main reason for disengagement with the Internet was a lack of interest. Hungary, Australia and New Zealand, countries which based on their Gini coefficient had expected or low levels of income-based digital exclusion (Figure 8) all cited this as the most important reason for non-use. This is in contrast to the countries with higher than expected income-based digital divides (the UK and the Czech Republic) where a lack of access and a lack of skills had more prominence than a lack of interest. Other research suggests that in Africa $^{8}$ and India $^{9}$ poor infrastructure is still a major impediment to Internet use.

\footnotetext{
8 https://www.budde.com.au/buddereports/4392/2007_Africa_-

_Telecoms_Mobile_and_Broadband_Overview.aspx?sub=EXECUTIVE

${ }^{9}$ https://www.budde.com.au/buddereports/2362/India_-

_Telecommunications_Infrastructure_-_National.aspx
} 
Figure 10. Most important reasons why people do not use the Internet

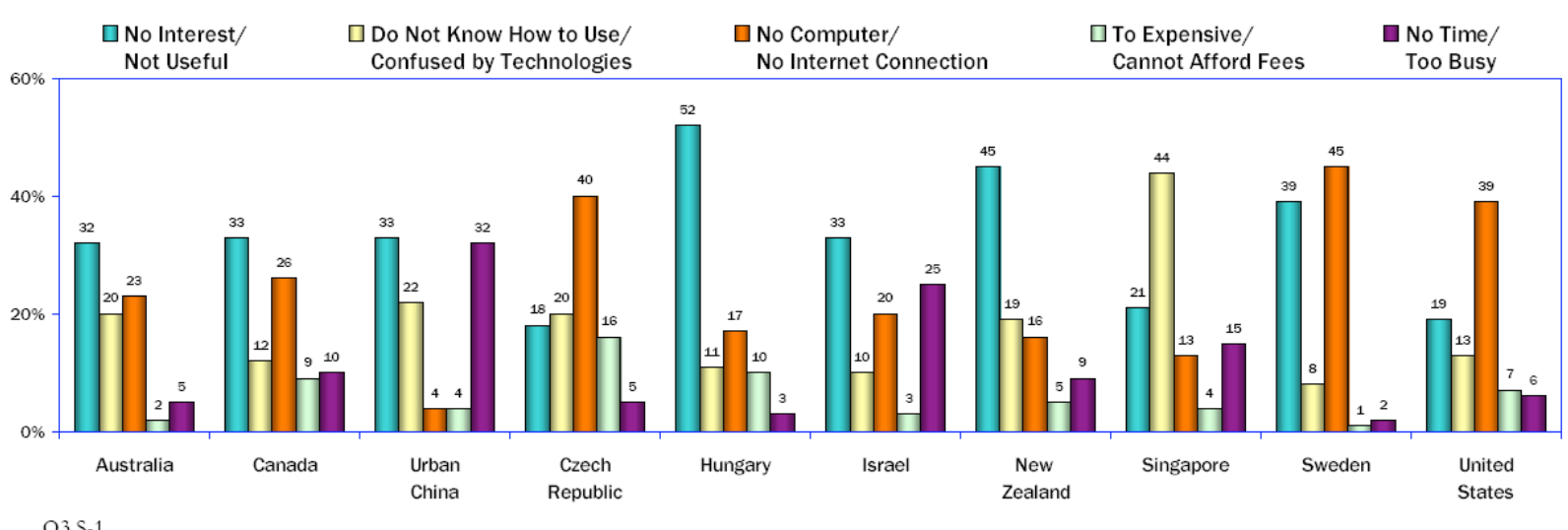

Source: World Internet Project International Report 2009 (p.80)

There were very few countries in WIP where a lack of access was the main reason for not using the Internet, suggesting that Internet infrastructure is now in place in most regions and that digital choice has become more important in disengagement from the Internet (Figure 10). Nevertheless, high diffusion countries like Sweden and the US still show large numbers of non-users who state a lack of access as the main reason for non-use. Therefore, we cannot conclude that digital exclusion will be automatically replaced by digital choice once diffusion reaches higher levels in Europe or countries in the Global South. Both are likely to remain significant issues.

\section{Attitudes and beliefs about the Internet}

One of the factors that influences whether or not people use the Internet and how important people judge the Internet to be are their attitudes towards the power that ICTs might have on people's lives. Again, as was the case for general Internet diffusion rates, globally, Britain occupies the middle ground, by combining high levels of trust in the information and services that are provided on the Internet with a tendency to be a bit more sceptical than other countries about the power of the Internet to transform everyday life. In this section we compare the attitudes towards political empowerment, economic participation and trustworthiness of information on the Internet in Britain and other countries.

\section{Political Empowerment}

The Internet has received attention from sociologists as a new public sphere or a realm in which citizens can come together and debate political issues, which will then influence government. Blogs, social networks and instant email access to politicians and political organisations have all been seen as means through which people could obtain more communicative power in politics. Nevertheless, the practice of everyday use tends to be slightly different. In Britain actual online political participation (Figures 11 and 12) is relatively low and only a very small subset of Internet users actively blog (Dutton and Helsper 2007). 
Figure 11

Number of Civic Activities
Undertaken Offline and the Number
Undertaken Online
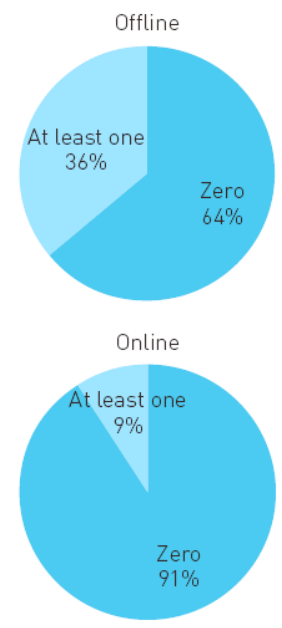

Current users. OxIS 2007: $\mathrm{N}=1,578$
Figure 12

Number of e-Government Activities

Undertaken on the Internet

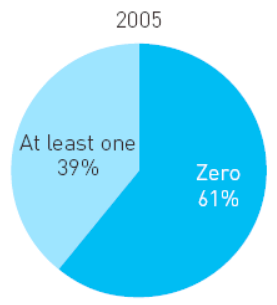

2007

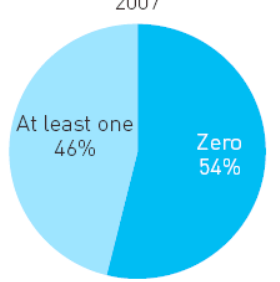

Current users. 0xIS 2005: $\mathrm{N}=1,309 ; 0 \times 15$ 2007: $\mathrm{N}=1,578$

Source: Dutton and Helsper (2007). Internet in Britain: 2007

British Internet users tended to be less optimistic than users in other countries about the power of the Internet to transform the significance of political participation. For example, in OxIS 2007 only 29 percent of UK respondents agreed somewhat or strongly with the statement "People like you can have more political influence", and only 27 percent agreed with the statement "People like you will have more to say about what the government does". Scepticism about the ability of the Internet to empower people politically was in general higher in the European countries, with the exception of the Czech Republic.

\section{Economic Participation and Trust}

Traditional political participation is low offline as well and in general politicians are not high up on people's most trusted list, it is therefore not too surprising that Internet users do not see the Internet as a source of political empowerment. Another area of empowerment is economic participation. Levels in trust in eCommerce activities mirror the low levels of trust found in relation to online political and civic activities.

Over two thirds of users in all countries were concerned about the security of buying things online with a credit card. This was an especially prominent issue in all the English-speaking countries, including Britain. Almost 90 percent of British users agreed or agreed strongly with the statement "People should be concerned about protection of credit card details when they are using new technologies" (Figure 13). 
Figure 13. Agreement with "People should be concerned about protection of credit card details when they are using new technologies" - Britain

Disagree strongly $\square$ Disagree $₫$ Neither agree nor disagree $\square$ Agree $\square$ Agree strongly

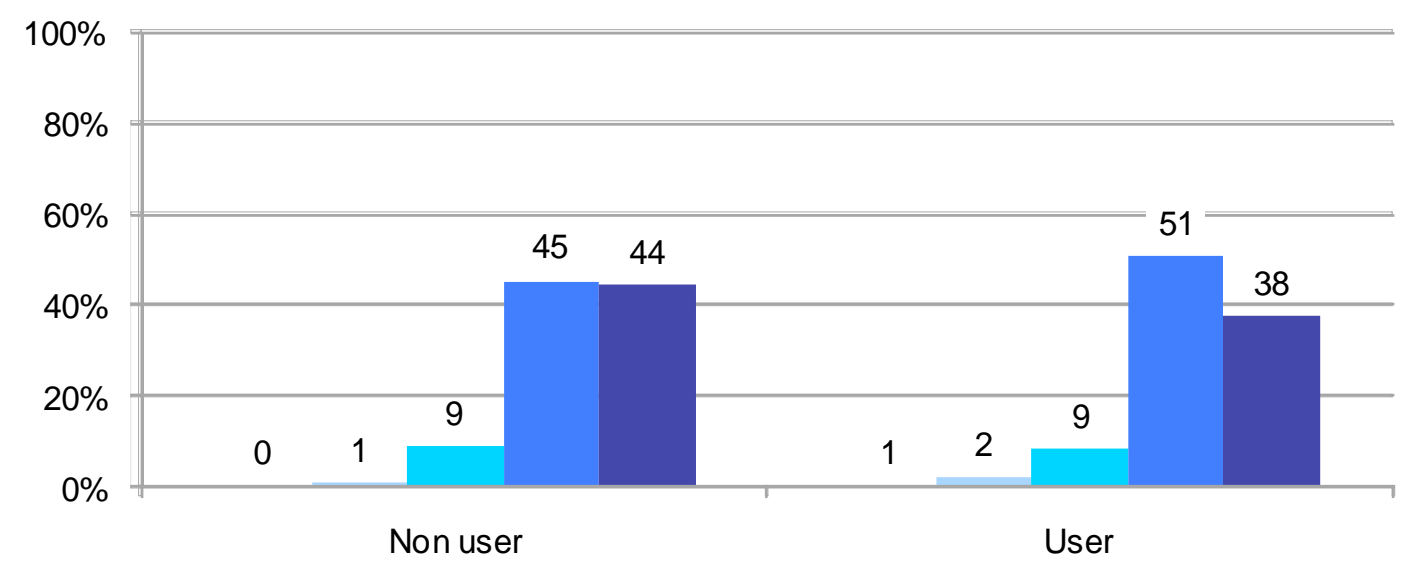

OxIS Base. Adult Users and Non-Users ( $N=2,255)$

Note: In WIP the question was 'Concerns about the security of credit card information when buying/purchasing online' (only asked to Internet Users)

Britons seem to be sceptical about the power that the Internet gives people to influence politics and to control their financial and personal information. This level of distrust is not present in the perception of these same Britons about the reliability of other types of information online.

\section{Trust in the Internet as an Information Source}

There is one other important way in which people can participate through the Internet that is potentially empowering. In the current networked world, economies thrive more on knowledge and innovation instead of industrial production, the mantra 'knowledge is power' is more applicable than it ever was. This is reflected in the Internet where knowledge acquisition and informal learning are amongst the most frequently used features and considered one of the most important opportunities that the Internet has to offer.

WIP data show that while Britons were sceptical about the power of the Internet to transform political influence and while they had some reservations about economic participation, they had fewer problems trusting the Internet to provide information. Over half of British Internet users thought that most or all of the information on the World Wide Web is reliable and accurate (Figure 14). 
Figure 14. How much of the information on the World Wide Web overall is generally reliable and accurate? - Britain

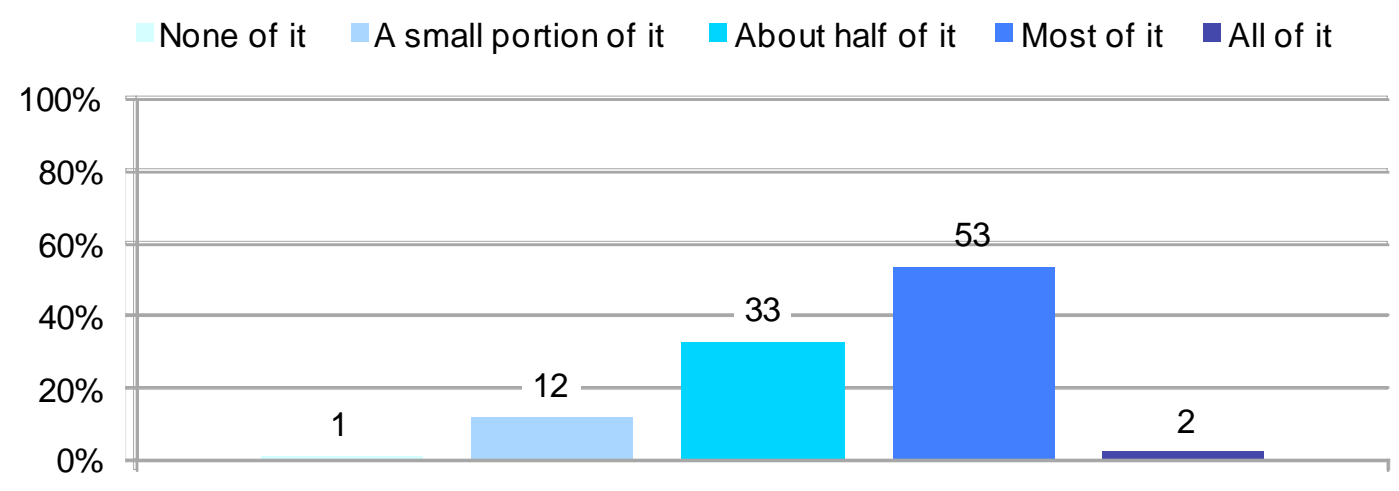

OxIS Base. Adult Internet Users $(N=1,492)$

Note: In WIP the users were asked 'How much of the information on the World Wide Web overall is generally reliable?'.

This attests to the importance of the Internet as an information source over and above any impact it might have as a source for political or economic empowerment. If trust in the information online does not suffer a decline in Britain the importance of the Internet as an information source is likely to increase over the next years. In sections that follow later in this paper the importance of the Internet in this area will be discussed further.

Figure 15. Trust in information on the Internet - WIP

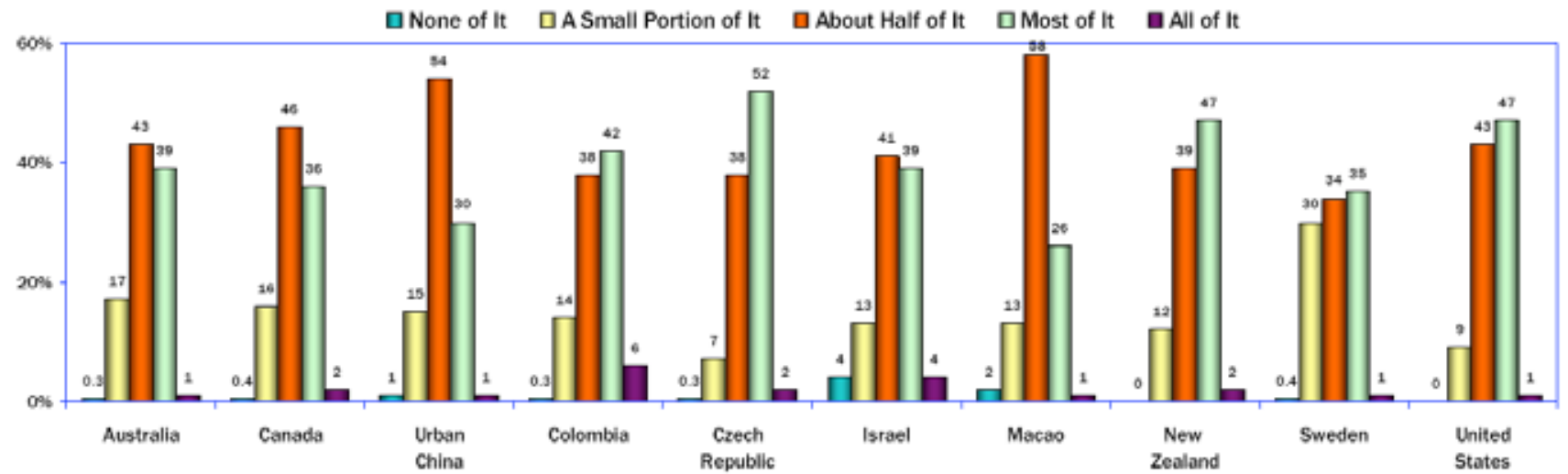

Q12 M-1

Source: World Internet Project International Report 2009 (p.260)

Other WIP countries tended to be more sceptical than Britons about the reliability of online information (Figure 15). An interesting note is that the level of trust is not clearly related to the level of diffusion of the Internet in a country. 


\section{Uses of the Internet}

While infrastructure and positive attitudes are clearly important in determining uptake of the Internet, ubiquitous access and a generally positive public opinion do not mean that everyone will use the Internet in the same manner (Helsper 2008). The Internet can be different things for different people, from an entertainment centre to a work station. For this reason, the WIP surveys have tracked the ways in which individuals choose to use the Internet and how this changes over time and across individuals and groups.

\section{Substitution and / or Complement}

A major issue of use is whether individuals substitute the Internet for other media, such as in reading the news online rather than purchasing a newspaper, or in complementary ways, supplementing their information acquisition by accessing news online in addition to reading the newspaper. While there currently is no clear and dramatic substitution effect, the long-term potential for substitution is uncertain. Moreover, the role of the Internet in relation to other media depends on the purposes for which individuals use the Internet in everyday life and work.

However, there is some indication that media habits are changing. For example, by 2007, the Internet had become the first port of call for Internet users in Britain when they looked for information of almost any kind. For learning, the Internet was the first choice for 72 percent of Internet users. This trend towards the Internet being the first place people go to for information reflects how central the Internet has become to people's everyday lives in this short time period. While the Internet is the most popular route when people seek quick answers or when they need information, this is not to say that it has become the most important source for information or entertainment in Britain or other nations around the world. Television, for example, still takes up a more prominent role in people's everyday lives even for those who go to the Internet first for information and entertainment (WIP 2009).

Globally television remains the most frequently used medium in the household. People spend significantly more hours per week watching TV than using the Internet. Britain is no exception to this general finding. In fact, Singapore was the only WIP country in 2007 where respondents reported spending more time using the Internet than watching television. Nevertheless, there is some indication of a possible substitution in that in all countries, Internet users report spending fewer hours a week watching TV than do non-users. In Britain, non-users said they watched TV 7.4 hours more per week than did Internet users. Of course, much of this differential can be explained by the demographic differences of Internet users and non-users, such as with respect to age.

In contrast to television, Britain is one of only three WIP countries where respondents indicate that they spend more time using the Internet than listening to the radio or reading newspapers. This suggests that the Internet has begun to play a role that is comparable to other media. In the following sections we will discuss in more detail the importance of the Internet for entertainment, information and communication purposes, the most frequently undertaken activities on the Internet. 


\section{Entertainment}

The dominance of TV is mostly due to its importance as a source for passive entertainment for Internet users and non-users. Of all the WIP countries only the Chinese and Colombian Internet users prefer the Internet over television for purposes of entertainment.

In Britain, 64 percent of Internet users considered the Internet to be important or very important for entertainment while 71 percent considered television to be important or very important, but only 17 percent thought it essential (Figure 16). In comparison, 63 percent of non- and ex-users considered television to be very important or important for their entertainment and 27 percent thought it was essential.

Figure 16. For entertainment in general, how important is each of the following to you as a source? - Britain

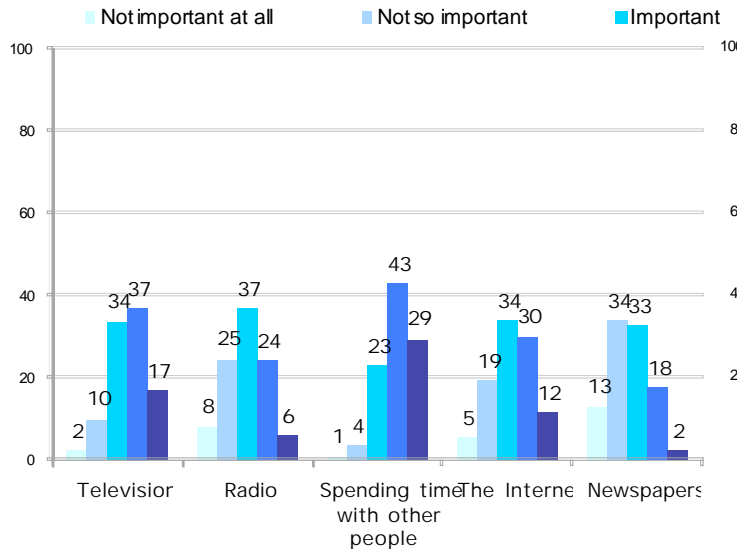

OxIS Base. Adult Internet Users $(N=1,492)$

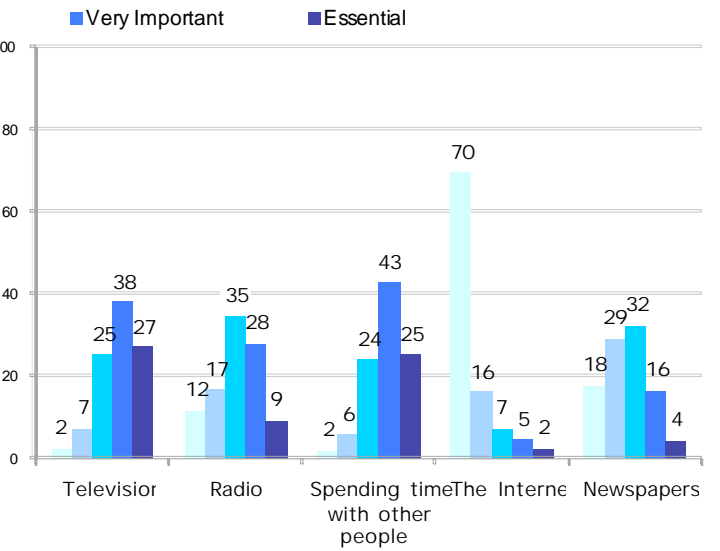

OxIS Base. Adult Ex and Non-Users ( $N=762)$

Note: In WIP the answer categories for this question were 'Not important at all' 'Not important', 'Neutral/Undecided', 'Important', and 'Very Important'.

\section{Information importance}

WIP shows that Internet users in European countries are different from those in other countries around the world in relation to the importance they attach to different media for gathering information. OxIS shows that the Internet has risen greatly in its perceived importance as a source for information in only two years (Dutton and Helsper 2007). This seems to be a global trend. Nevertheless, for Britons who use the Internet, but also for non-users, the most important source of information remained other people, followed by the Internet for Internet users, and television for non-users (Figure 17). 
Figure 17. For information in general, how important is each of the following to you as a source

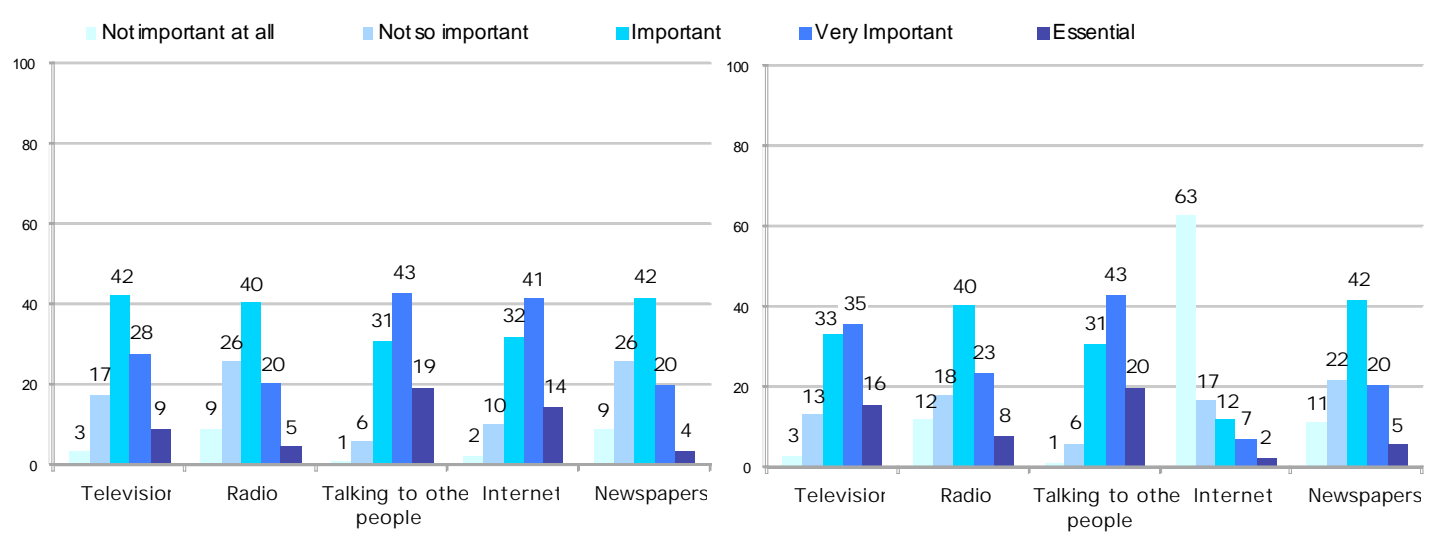

OxIS Base. Adult Internet Users $(N=1,492)$

OxIS Base. Adult Ex and Non-Users $(N=762)$

Note: In WIP the answer categories for this question were 'Not important at all', 'Not important', 'Neutral/Undecided', 'Important', and 'Very Important'.

This pattern is similar to that in Eastern European countries. It is important to keep in mind that while British Internet users considered interpersonal sources more important than the Internet for obtaining information, when asked a different question, they said that they would go to the Internet first if they had to look for information. This suggests that while Britons think that the information obtained through face-toface contact is more valuable, the Internet is more readily available, and is, therefore, the first port of call when people need a quick and easy answer.

\section{Social interaction and networking importance}

There has been a continuing debate over whether the Internet has become a substitution for face-to-face contact with other people. Some argue that its use reinforces existing networks and others that it reconfigures social networks, such as by giving people access to people they would not normally have met. OxIS provides evidence for both these positions; 23 percent of Internet users in Britain said they have met or contacted people through the Internet whom they had not met before (Dutton and Helsper 2007). That is, while most people primarily communicate with individuals they know, reinforcing their social networks, a sizeable proportion meet new people, reconfiguring their social networks.

Generally, however, people do not believe that the Internet is reconfiguring their relationships with others. In WIP, Britain was amongst the countries with the highest percentage of people who thought that the Internet had not changed the amount of time they interacted with other people from similar backgrounds (Figure 18). 
Figure 18. Has the use of the Internet increased or decreased your contact with...?

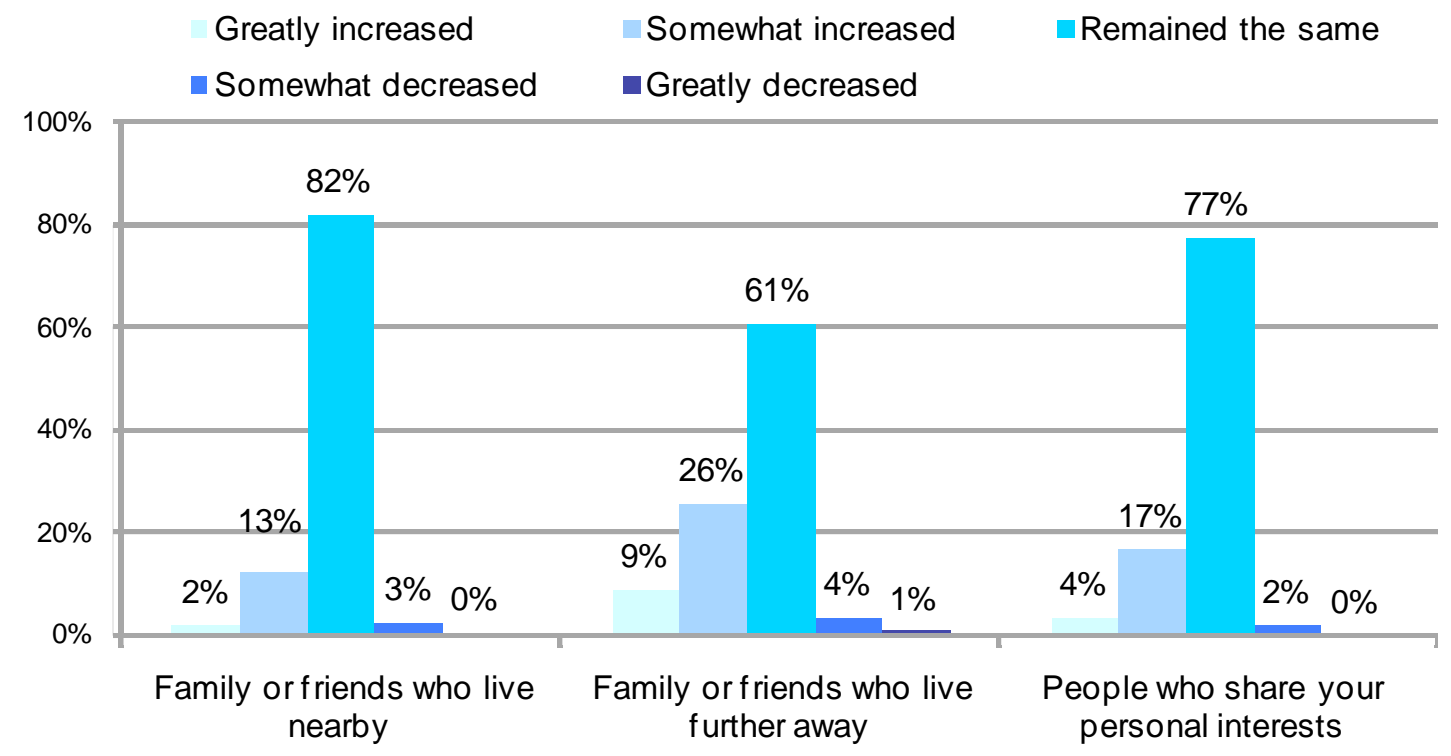

OxIS Base. Adult Internet Users $(N=1,492)$

Note: In WIP the users were asked whether they increased or decreased the time they spent with family and separately whether they spent time with friends (no distinction was made between those who live nearby and those who live further away). In addition, users were asked whether the Internet increased the time spent with people who share recreational activities instead of personal interests.

From Figure 18 it is clear that British users assumed that, if anything had changed at all, the contact they had with their friends and family had increased (15 to 31 percent argued this). Internet users in Britain were more likely than Internet users in other countries to say that the time they spent face-to-face with members of their family and friends had not changed due to their Internet use. Based on WIP findings, Internet users in the United States, Australia, and the other European countries are more likely to think that the time spent face-to-face with family and friends has decreased (between 4 and 16 percent argued this).

The WIP and OxIS findings thus support the notion of complementarity versus substitution in the UK, but not necessarily in the rest of the world. The Internet users in the UK are likely to use the Internet to complement their existing sources of entertainment and socializing. However, there was some evidence that globally, the Internet is perceived to be taking prominence over other media in finding information and learning.

\section{Multitasking}

As discussed above, the Internet has not replaced other offline behaviours in as much as it has offered additional tools to access information, people and services to those with access to the Internet. This is reflected in the high levels of multi-tasking observed around the world; people commonly undertake other activities while they are online. However, WIP suggests that multi-tasking is not as widespread in Britain as elsewhere in the world. Nevertheless, 63 percent of British Internet users said they undertook other activities while using the Internet. Respondents in Hungary and Australia were the only two countries where Internet users were less likely than in Britain to say they multitask. At the opposite end of the scale, in countries such as the US and urban China, more than three quarters of Internet users indicated that they multi-tasked. 


\section{Internet Use Patterns}

Given the growing importance of the Internet and its integration into everyday life, what do people do when they are online? To gauge this, the WIP surveys asked respondents to rate the frequency with which they use the Internet to perform a variety of different internet activities. An important indicator of the position of a country within this increasingly networked world is the level to which users are active in the more complex (eg. Web 2.0) uses of the Internet and to what extent they engage with more common uses such as information seeking. The WIP data show that uses of Web 2.0 application in communication were still comparatively low across the globe and Britain is neither a forerunner nor a laggard in this area in comparison to other countries.

Britons were comparatively high in the uptake of the advanced finance-related applications of the Internet, while at the same time engaging with more basic Internet activities such as basic communication. These basic activities include information seeking, and Britain's high levels of engagement reflect the higher levels of trust observed earlier. For financial transactions the same is not true; the high levels of distrust observed in the previous section were not mirrored in low levels of use of financial services online. It is therefore not clear that trust leads to use or that vice versa, a lack of trust leads to disengagement (see also Helsper et al 2008).

\section{Different Uses of the Internet}

Besides interaction with other media while engaging with the internet, Internet use itself often involves a wide range of different types of engagement. Many Internet users have an internet chat box open while looking for information for work or study and simultaneously listening to music streamed live online. The rest of this paper will therefore look at the different uses of the Internet.

OxIS inquires into a broader range of Internet uses than the core WIP survey. All 49 different activities enquired into by OxIS can be combined into 12 different genres of Internet use (see Appendix). Shopping and comparing products and services were the most popular, as well as uses relating to information seeking and entertainment. The least popular activities are the Web 2.0 applications and those activities relating to political and civic participation (Figure 19). 
Figure 19. Uses of the Internet in Britain

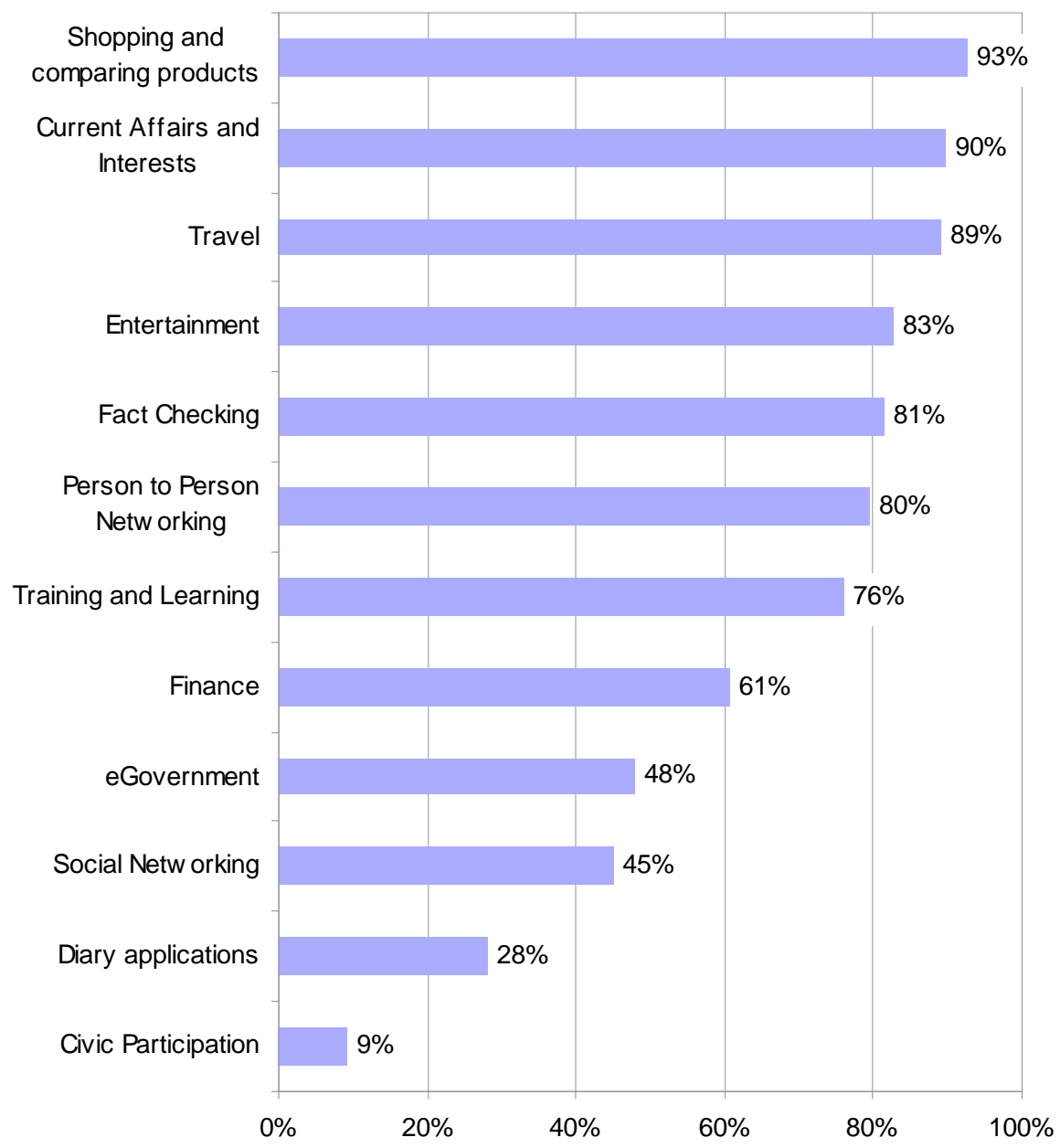

OxIS Base. Adult Internet Users ( $N=1,492)$

Note: The 12 different genres were based on a factor analysis (see Appendix). Percentages indicate the proportion of Internet Users who undertook this type of activity at least once in the last year.

In each of the other countries these uses were distributed differently, which suggests that even if diffusion, skills and attitudes towards the technology are comparable this does not mean that as researchers we can assume that patterns of use will be the same. In the rest of this section we will discuss a few particular aspects of use that were measured across all countries in the World Internet Project: multitasking, communication, information and learning, entertainment, and ecommerce and finance. For each activity Britain shows patterns of engagement different to those of the other nations but in general it is in the basic uses, such as communication, where British users were amongst the most active in the world.

\section{Communication}

Britain was among the WIP countries with the highest use of the Internet for communication purposes, such as for checking e-mail, instant messaging and participating in chat rooms. Especially in a European context, the British Internet users were very active communicators. 68 percent said they checked their emails at least once per day. Britons tended to use the Internet more for communication than Internet users in Sweden (59 percent uses email daily) and Hungary (61 percent emails daily). The Czech Republic was on a par with the UK in basic communication 
uses of the Internet. However, the use of the Internet for more innovative ways of communicating, such as making or receiving phone calls and blogging, was relatively low in Britain, when placed in a European or global context.

\section{Information and Learning}

Where Britain stands globally in relation to information searches varies greatly depending on the type of information. Britain has low or average levels of people undertaking formal and informal learning opportunities online. On the other hand, British Internet users showed high levels of using the Internet to look for practical information that could help the user deal with immediate problems, such as looking for a job and finding or checking a fact. In a European context, Britain was more similar to the Eastern European WIP countries than to Sweden with respect to using the Internet for finding information. Sweden had low levels of online information seeking (for example, in Britain 32 percent never looked for health information, in Sweden 46 percent never did) with the exception of looking for news which was more prevalent in Sweden (49 percent looked for news daily, in Britain 17 percent did this).

\section{Entertainment and Leisure}

Activities that were traditionally shared with close friends and family, that is music and video consumption, playing games and looking for jokes, were low or average in comparison to most other countries in WIP. Downloading music and videos was not undertaken by a majority of Internet users in Britain, 34 percent of Internet users downloaded music monthly and only 19 percent downloaded videos this frequently (Figure 20). Within Europe, the Czech Republic tended to have higher (eg. 59 percent played games) and Sweden lower participation (eg. only 32 percent played games) for almost all these uses.

Figure 20. How frequently do you use the Internet for the following purposes?

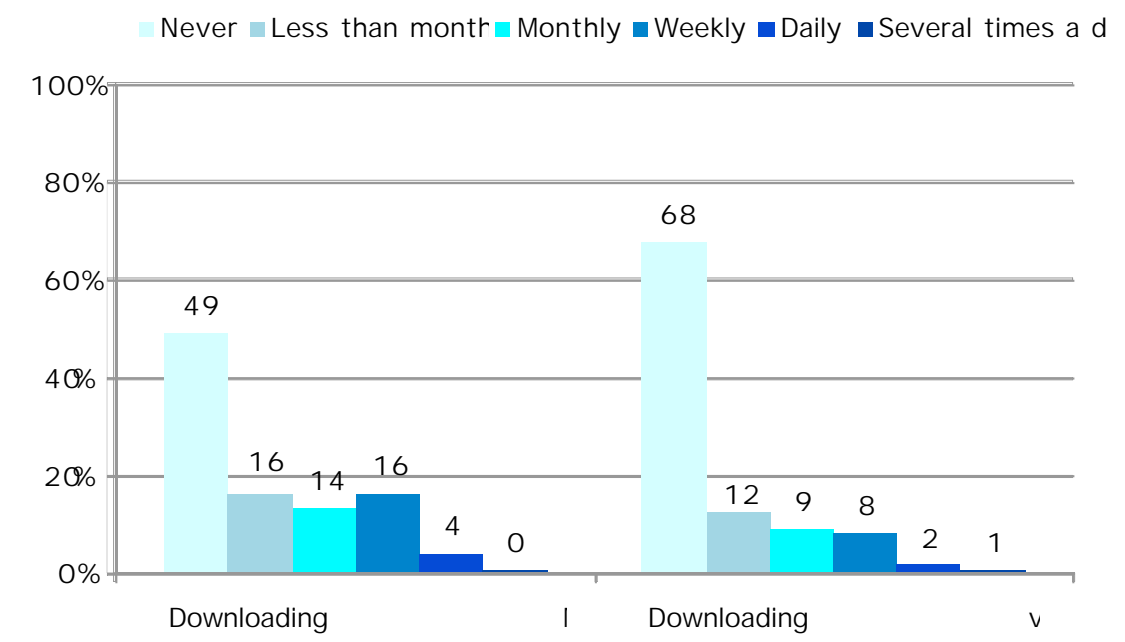

OxIS Base. Adult Internet Users $(N=1,492)$

Note: In WIP the questions were phrased as 'downloading or listening to music', 'downloading or watching videos'.

However, for leisure pursuits, such as looking for travel information and making reservations as well as for online gambling, the British Internet users were more active than those in other countries. 
WIP also investigated a number of online activities with a moral or normative aspect to them (religious and sexual content) and Britain was comparatively inactive on both of these. Compared with the US, for example, European WIP countries, including Britain, showed the lowest use of the Internet for looking at religious or spiritual sites (ie. 9 percent of users in comparison to 33 percent in the US).

\section{eCommerce and Finance}

Information, communication and entertainment are more traditional genres of use associated with the Internet as well as with other media. The Internet, however, offers access to services that might be difficult to access through traditional media. British Internet users use the Internet quite frequently for online and commerce activities, for example, 69 percent gets information about a product or service monthly and 26 percent checks investments at least once per year (Figure 21).

Figure 21. How frequently do you use the Internet for the following purposes?

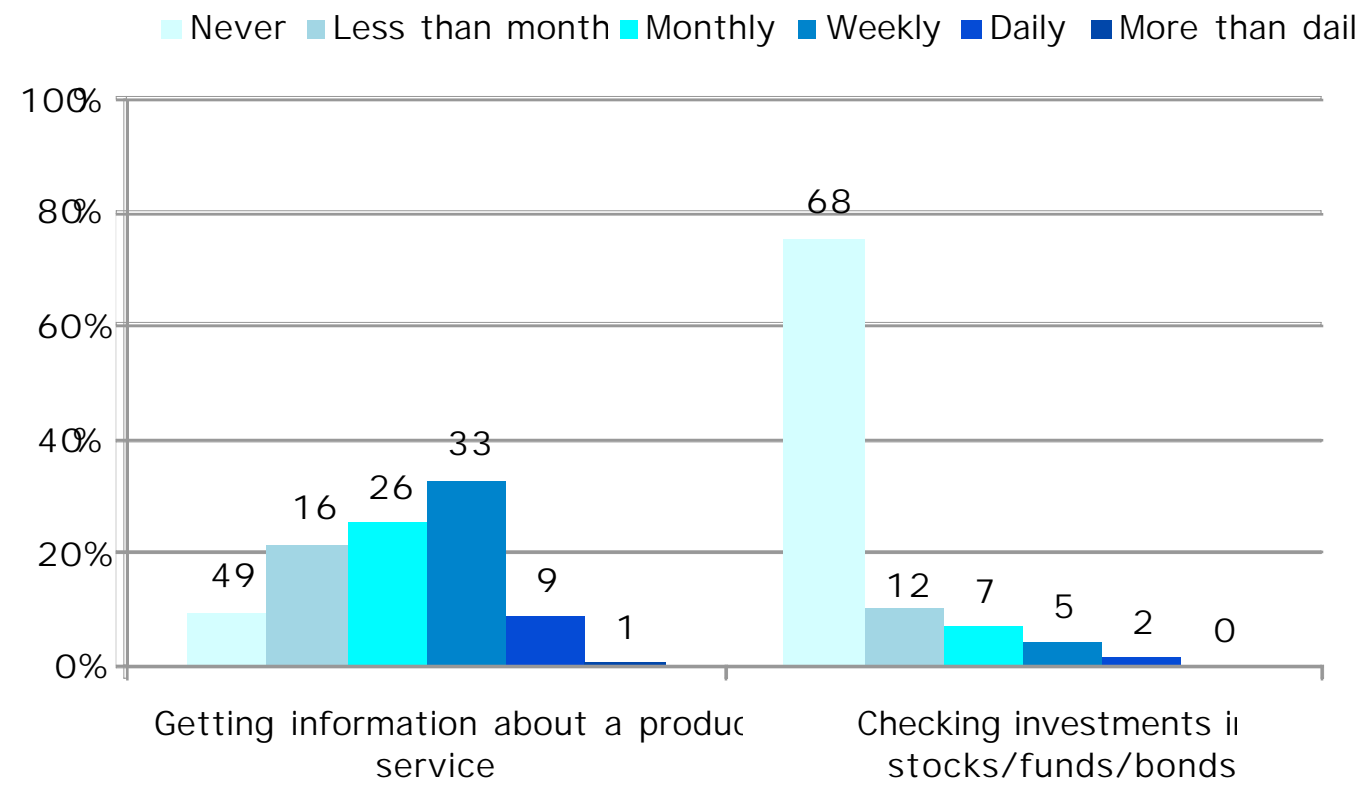

OxIS Base. Adult Internet Users $(N=1,492)$

Note: In WIP the questions were phrased as 'looking for information about products', and 'to invest in stocks/bonds'.

Internet users in Britain tend to participate more heavily in these commerce and finance activities than Internet users in other countries. As regards buying and looking for products or financial products such as stocks and bonds, they show similar (high) levels to the US, while for online banking they are ranked higher than Eastern European countries but lower than the US and Sweden (Figure 22). 
Figure 22. How frequently do you use the Internet to use your bank's online services? WIP

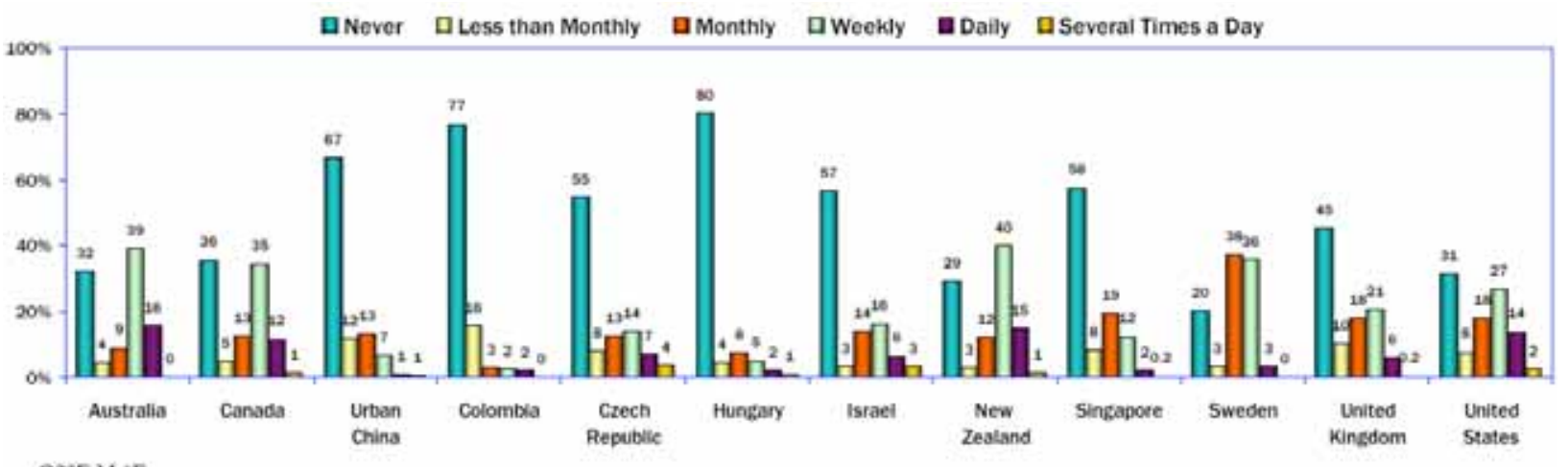

Q23E M-1E

Source: World Internet Project International Report 2009 (p.163)

\section{Conclusions}

Britons were not the early adopters of the Internet, nor were they laggards. They seemed as a nation to move through a period of indecision, first about the Internet, and later about the move to broadband. In a way this national indecision about whether to be or not a networked nation is reminiscent of the famous Shakespearean tragedy of Hamlet. Famously, of course, Hamlet's decisions turned out for the worst, but Britain's recent steps towards inclusion in a networked world appear to have put it on a sound course.

The evidence suggests that after a period in which there was collective political doubt about the use of the Internet it now seems that sentiment in Britain has shifted. Most Britons have made the decision to become part of this new global network society. Around the world, and clearly also in Britain, the Internet has taken on an important role as a source for information. It does not substitute for old media but the rise and convergence alongside other media, such as television, is placing the Internet in an increasingly important role.

Britain was relatively late to move to broadband, and, more recently, to gain access to the Internet over mobile devices. It is also hesitating relative to the lead nations, such as Korea, and most recently the US, to prioritize high-speed broadband Internet. Now, as in the recent past, Britain has not been at the leading-edge of innovation, but it is in the pack of nations leading the world in the use of the Internet across a wide range of activities. Once online Britons seem to be relatively more engaged in taking up those activities that have been considered advanced in other countries, such as Web 2.0 and other interactive applications. Britain has made its decision to be a network nation, but faces new choices and risks of indecision over emerging developments. 


\section{References}

Dutton, W.H. and Helsper, E.J. (2007) The Internet in Britain (Oxford Internet Institute, University of Oxford). Available at: http://oii.ox.ac.uk/microsites/oxis/

Dutton, W.H., di Gennaro, C. and Hargrave, A.M. (2005) The Internet in Britain: The Oxford Internet Survey (OxIS) (Oxford Internet Institute, University of Oxford).

Dutton, W.H., Gillett, S.E., McKnight, L.W. and Peltu, M. (2004) Bridging Broadband Internet Divides: Reconfiguring Access to Enhance Communicative Power. Journal of Information Technology 19:28-38.

Eurobarometer (2008) E-Communications Household Survey. Report for the European Commission. Retrieved September 2008 from:

http://ec.europa.eu/public_opinion/archives/ebs/ebs_293_full_en.pdf

Helsper, E.J. (2008) Digital Inclusion: An Analysis of Social Disadvantage and the Information Society (Communities and Local Government: London).

Helsper, E.J, Dutton, W.D., Gerber, M. and Reisdorf, B. (2008) Trust and the Internet: Experience technology or certainty trough models? Paper presented at the 2008 European Communication Conference in Barcelona. Available at: http://www.oii.ox.ac.uk/microsites/oxis/publications

WIP (2009) The World Internet Project, International Report 2009 (USC Annenberg Centre for the Digital Future: Los Angeles, CA).

Wyatt, S., Thomas, G. and Terranova, T. (2002) They Came, They Surfed, They Went Back to the Beach: Conceptualizing Use and Non-Use of the Internet. In: S.Woolgar (ed.) Virtual Society? Technology, Hyperbole, Reality (Oxford University Press: Oxford), pp. 23-40.

\section{About the Authors}

William H. Dutton is Professor of Internet Studies and Director of the Oxford Internet Institute, University of Oxford, and Principal Investigator of OxIS.

Monica Gerber is a Doctoral student at the London School of Economics, and a Survey Research Assistant at the Oxford Internet Institute.

Ellen J. Helsper is a Survey Research Fellow at the Oxford Internet Institute, University of Oxford, and Co-ordinator of the Oxford Internet Surveys (OxIS). 


\section{Appendix}

\begin{tabular}{|c|c|c|c|c|c|c|c|c|c|c|c|c|}
\hline & $\begin{array}{l}\text { Civic } \\
\text { participation }\end{array}$ & Entertainment & Egov & Learning & Finance & Shopping & $\begin{array}{l}\text { Person } \\
\text { to person } \\
\text { network }\end{array}$ & $\begin{array}{l}\text { Social } \\
\text { network }\end{array}$ & News & Travel & Diary & Hobby \\
\hline $\begin{array}{l}\text { Contacted a politician, government or local } \\
\text { government official }\end{array}$ & 0.98 & 0.00 & 0.02 & 0.01 & 0.01 & 0.01 & 0.01 & 0.01 & 0.02 & -0.01 & 0.02 & 0.00 \\
\hline $\begin{array}{l}\text { Deliberately bought certain products for } \\
\text { political, ethical or environmental reason }\end{array}$ & 0.98 & 0.00 & 0.00 & 0.03 & 0.02 & 0.02 & 0.01 & 0.00 & 0.02 & -0.01 & 0.01 & 0.01 \\
\hline Joined another civic organisation & 0.95 & 0.01 & 0.00 & 0.01 & 0.00 & 0.01 & 0.01 & -0.02 & 0.00 & -0.02 & 0.01 & 0.01 \\
\hline $\begin{array}{l}\text { Donated money to a political organisation or } \\
\text { group }\end{array}$ & 0.90 & 0.00 & -0.02 & 0.01 & 0.00 & 0.00 & -0.01 & -0.02 & 0.01 & -0.01 & 0.01 & 0.00 \\
\hline Signed a petition & 0.88 & -0.02 & 0.05 & 0.01 & 0.04 & 0.03 & 0.04 & 0.00 & 0.03 & 0.02 & -0.01 & 0.01 \\
\hline Contacted a political party & 0.86 & 0.03 & 0.01 & 0.03 & -0.01 & -0.04 & 0.00 & 0.04 & 0.04 & -0.01 & -0.02 & 0.03 \\
\hline Taken part in a lawful public demonstration & 0.86 & 0.02 & 0.01 & 0.01 & 0.00 & -0.01 & -0.02 & -0.01 & 0.01 & 0.02 & -0.02 & 0.02 \\
\hline Joined a political party & 0.85 & 0.02 & 0.02 & 0.03 & -0.02 & -0.01 & 0.01 & 0.01 & -0.03 & 0.00 & 0.02 & -0.01 \\
\hline Downloading music & -0.05 & 0.78 & 0.02 & 0.05 & 0.09 & 0.12 & 0.05 & 0.13 & 0.03 & 0.00 & 0.06 & 0.07 \\
\hline Downloading videos & -0.05 & 0.78 & 0.07 & 0.05 & 0.07 & 0.06 & 0.03 & 0.11 & 0.02 & 0.03 & 0.02 & 0.03 \\
\hline Playing games & 0.05 & 0.61 & -0.02 & 0.10 & 0.00 & 0.06 & 0.11 & 0.03 & 0.05 & -0.07 & 0.03 & 0.05 \\
\hline Participate in chat rooms & 0.07 & 0.45 & -0.03 & 0.08 & -0.07 & -0.01 & 0.22 & 0.20 & 0.03 & 0.00 & 0.22 & 0.07 \\
\hline Surfing or browsing the Web & 0.01 & 0.35 & 0.12 & 0.00 & 0.08 & 0.32 & 0.16 & 0.23 & 0.16 & -0.03 & 0.00 & 0.17 \\
\hline Listening to a radio station online & 0.01 & 0.39 & 0.18 & 0.06 & 0.05 & 0.07 & 0.10 & 0.17 & 0.12 & 0.06 & 0.10 & 0.09 \\
\hline Do instant messaging & 0.05 & 0.36 & 0.05 & 0.06 & 0.00 & 0.17 & 0.31 & 0.32 & 0.03 & -0.06 & 0.16 & 0.13 \\
\hline Looking at 'adult' sites with sexual content & -0.01 & 0.32 & 0.03 & -0.01 & 0.00 & 0.02 & 0.16 & 0.07 & 0.10 & 0.11 & 0.10 & 0.01 \\
\hline
\end{tabular}

Note: Factor analyses continue on next two pages

The coloured cells correspond to those variables that loaded higher than .30. These were included in the composite scales. 


\begin{tabular}{|c|c|c|c|c|c|c|c|c|c|c|c|c|}
\hline & $\begin{array}{l}\text { Civic } \\
\text { participation }\end{array}$ & Entertainment & Egov & Learning & Finance & Shopping & $\begin{array}{l}\text { Person } \\
\text { to person } \\
\text { network }\end{array}$ & $\begin{array}{l}\text { Social } \\
\text { network }\end{array}$ & News & Travel & Diary & Hobby \\
\hline $\begin{array}{l}\text { Get information about government policy on } \\
\text { issues }\end{array}$ & 0.01 & 0.08 & 0.71 & 0.06 & 0.05 & 0.02 & 0.09 & 0.05 & 0.08 & 0.06 & 0.00 & 0.12 \\
\hline $\begin{array}{l}\text { To look for information about an MP, local } \\
\text { councillor, politicians }\end{array}$ & 0.02 & 0.06 & 0.67 & 0.06 & -0.04 & 0.02 & 0.01 & 0.03 & 0.07 & 0.06 & -0.03 & 0.07 \\
\hline To get information about local council services & 0.02 & 0.04 & 0.65 & 0.07 & 0.12 & 0.13 & 0.07 & 0.01 & 0.13 & 0.03 & 0.05 & -0.01 \\
\hline $\begin{array}{l}\text { To get information about Central Government } \\
\text { services }\end{array}$ & 0.01 & -0.05 & 0.60 & 0.05 & 0.15 & 0.08 & 0.12 & 0.04 & 0.07 & 0.08 & 0.02 & 0.05 \\
\hline $\begin{array}{l}\text { To get information about schools or education } \\
\text { To pay for a central government tax, fine, }\end{array}$ & 0.02 & 0.11 & 0.48 & 0.27 & 0.05 & 0.07 & 0.04 & 0.09 & 0.01 & 0.01 & 0.00 & 0.00 \\
\hline license or service & 0.00 & 0.00 & 0.40 & 0.02 & 0.20 & 0.05 & 0.02 & -0.01 & 0.05 & 0.05 & 0.15 & -0.03 \\
\hline $\begin{array}{l}\text { To pay for a local council tax, fine, rent or } \\
\text { service online }\end{array}$ & -0.01 & 0.07 & 0.35 & 0.05 & 0.27 & 0.09 & -0.02 & -0.02 & 0.10 & 0.05 & 0.09 & 0.07 \\
\hline $\begin{array}{l}\text { Distance learning for an academic degree or job } \\
\text { training }\end{array}$ & 0.03 & 0.01 & 0.07 & 0.67 & 0.05 & 0.04 & 0.07 & 0.02 & 0.06 & 0.08 & 0.09 & 0.01 \\
\hline $\begin{array}{l}\text { Finding out about opportunities for further study } \\
\text { about topics }\end{array}$ & 0.03 & 0.12 & 0.17 & 0.57 & 0.02 & 0.20 & 0.16 & 0.06 & 0.21 & 0.01 & 0.11 & 0.22 \\
\hline $\begin{array}{l}\text { Getting information for school related projects } \\
\text { or homework }\end{array}$ & 0.05 & 0.15 & 0.12 & 0.57 & 0.03 & 0.01 & 0.01 & 0.19 & -0.04 & -0.03 & 0.00 & 0.19 \\
\hline Getting information for work related projects & 0.01 & 0.04 & 0.24 & 0.39 & 0.07 & 0.24 & 0.24 & 0.01 & 0.10 & 0.06 & 0.10 & 0.23 \\
\hline Investigating topics of personal interest & 0.00 & 0.19 & 0.19 & 0.33 & 0.06 & 0.33 & 0.17 & 0.09 & 0.26 & -0.01 & 0.01 & 0.32 \\
\hline Paying bills & -0.01 & 0.05 & 0.22 & 0.04 & 0.80 & 0.18 & 0.08 & 0.05 & 0.12 & 0.20 & 0.03 & 0.04 \\
\hline Using your bank's online services & 0.02 & 0.05 & 0.20 & 0.08 & 0.77 & 0.21 & 0.09 & 0.13 & 0.09 & 0.11 & -0.03 & 0.03 \\
\hline Checking investments in stocks/funds/bonds & 0.00 & 0.00 & 0.26 & 0.06 & 0.33 & 0.13 & 0.09 & -0.06 & 0.09 & 0.13 & 0.19 & 0.06 \\
\hline
\end{tabular}




\begin{tabular}{|c|c|c|c|c|c|c|c|c|c|c|c|c|}
\hline & $\begin{array}{l}\text { Civic } \\
\text { participation }\end{array}$ & Entertainment & Egov & Learning & Finance & Shopping & $\begin{array}{l}\text { Person } \\
\text { to person } \\
\text { network }\end{array}$ & $\begin{array}{l}\text { Social } \\
\text { network }\end{array}$ & News & Travel & Diary & Hobby \\
\hline Getting information about a product or service & -0.01 & 0.18 & 0.15 & 0.13 & 0.19 & 0.64 & 0.10 & 0.08 & 0.19 & 0.14 & 0.06 & 0.15 \\
\hline Comparing products and prices & 0.00 & 0.11 & 0.18 & 0.15 & 0.21 & 0.63 & 0.16 & 0.11 & 0.12 & 0.08 & 0.05 & 0.06 \\
\hline Buying a product or service online & -0.03 & 0.17 & 0.20 & 0.14 & 0.30 & 0.53 & 0.09 & 0.08 & 0.06 & 0.34 & 0.03 & -0.04 \\
\hline Send jokes or other humorous content to others & -0.01 & 0.31 & 0.08 & 0.12 & 0.04 & 0.06 & 0.70 & 0.10 & 0.04 & 0.04 & 0.04 & -0.01 \\
\hline Send attachments with your email & 0.01 & 0.15 & 0.25 & 0.12 & 0.11 & 0.24 & 0.53 & 0.14 & 0.09 & 0.14 & 0.10 & 0.21 \\
\hline Check your email & 0.01 & 0.14 & 0.21 & 0.06 & 0.19 & 0.23 & 0.38 & 0.19 & 0.11 & 0.09 & 0.03 & 0.16 \\
\hline Created a profile on a social networking site & -0.02 & 0.27 & 0.06 & 0.08 & 0.02 & 0.04 & -0.04 & 0.66 & 0.00 & -0.02 & 0.20 & 0.04 \\
\hline $\begin{array}{l}\text { Posted messages on discussion or message } \\
\text { boards }\end{array}$ & -0.01 & 0.20 & 0.07 & 0.11 & 0.09 & 0.10 & 0.14 & 0.59 & 0.06 & -0.02 & 0.13 & 0.05 \\
\hline Posted pictures or photos on the Internet & 0.01 & 0.15 & -0.02 & 0.08 & 0.00 & 0.04 & 0.19 & 0.55 & 0.04 & 0.10 & 0.15 & 0.08 \\
\hline Getting information about local events & 0.07 & 0.21 & 0.16 & 0.16 & 0.12 & 0.15 & 0.09 & 0.01 & 0.64 & 0.11 & 0.08 & 0.11 \\
\hline Looking for news - local, national, international & 0.00 & 0.12 & 0.32 & 0.08 & 0.16 & 0.18 & 0.12 & 0.11 & 0.61 & 0.07 & 0.04 & 0.11 \\
\hline Looking for sports information & 0.04 & 0.30 & 0.15 & 0.04 & 0.09 & 0.05 & 0.07 & 0.02 & 0.42 & 0.19 & 0.00 & 0.06 \\
\hline $\begin{array}{l}\text { Finding information about health or medical } \\
\text { care }\end{array}$ & -0.02 & 0.03 & 0.21 & 0.28 & 0.11 & 0.16 & 0.03 & 0.06 & 0.36 & 0.24 & 0.09 & 0.05 \\
\hline Making travel reservations/bookings & -0.02 & 0.04 & 0.14 & 0.03 & 0.28 & 0.21 & 0.07 & -0.01 & 0.07 & 0.71 & 0.05 & 0.08 \\
\hline Making travel plans & -0.01 & 0.07 & 0.19 & 0.13 & 0.16 & 0.06 & 0.10 & 0.06 & 0.25 & 0.68 & -0.01 & 0.06 \\
\hline Maintain a personal website & 0.02 & 0.15 & 0.06 & 0.11 & 0.05 & 0.07 & 0.08 & 0.23 & 0.01 & -0.02 & 0.67 & 0.04 \\
\hline Write a blog & -0.03 & 0.14 & 0.05 & 0.13 & 0.06 & 0.01 & -0.03 & 0.31 & 0.02 & 0.01 & 0.66 & 0.05 \\
\hline Make or receive phone calls over the Internet & 0.00 & 0.25 & 0.16 & 0.00 & 0.05 & 0.02 & 0.20 & 0.06 & 0.12 & 0.09 & 0.42 & 0.02 \\
\hline Finding or checking a fact & 0.02 & 0.18 & 0.14 & 0.34 & 0.08 & 0.19 & 0.16 & 0.12 & 0.18 & 0.06 & 0.09 & 0.71 \\
\hline Looking up a definition of a word & 0.06 & 0.19 & 0.17 & 0.33 & 0.03 & 0.08 & 0.03 & 0.18 & 0.12 & 0.12 & 0.06 & 0.58 \\
\hline
\end{tabular}

